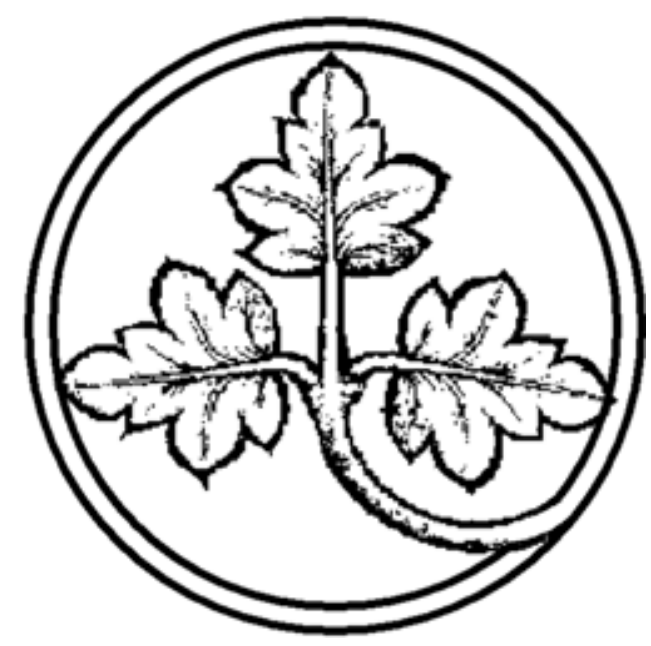

\author{
Preprints of the \\ Max Planck Institute \\ for Research on Collective Goods \\ Bonn \\ 2004/13
}

The Impact of Representation Norms on the Quality of Judicial Decisions

Christoph Engel 


\section{The Impact of Representation Norms on the Quality of Judicial Decisions}

Christoph Engel

November 2004 


\section{The Impact of Representation Norms on the Quality of Judicial Decisions}

\section{Christoph Engel}

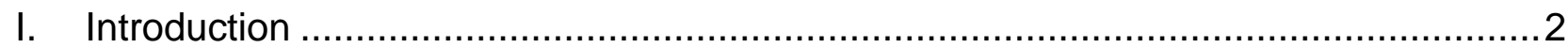

1. Normative Starting Point .............................................................................

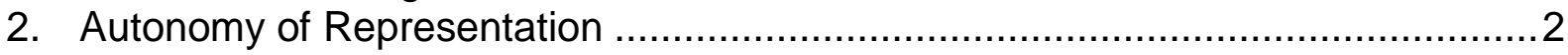

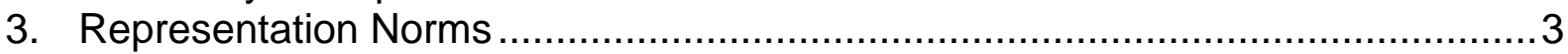

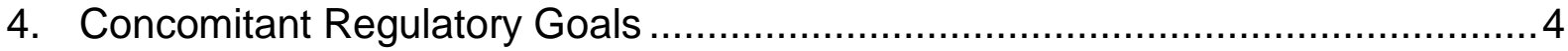

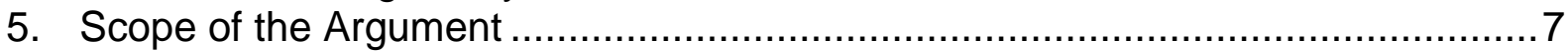

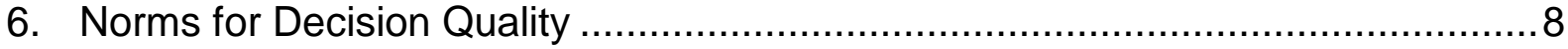

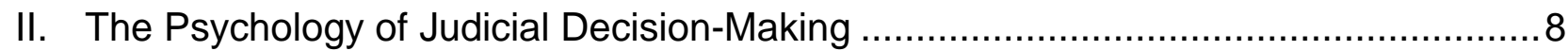

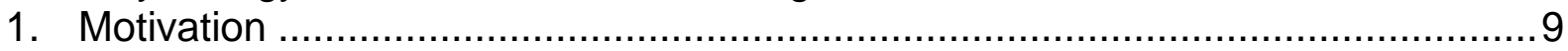

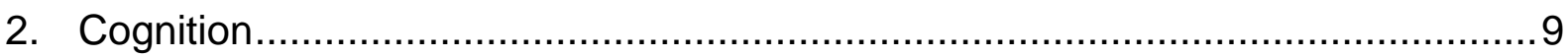

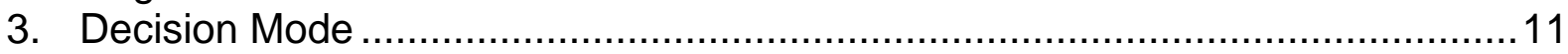

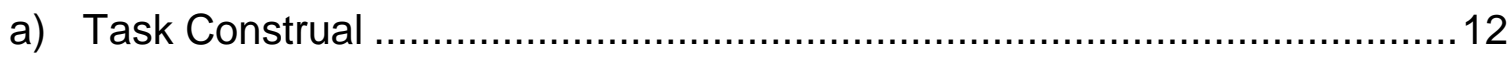

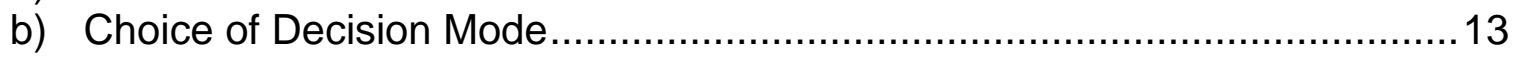

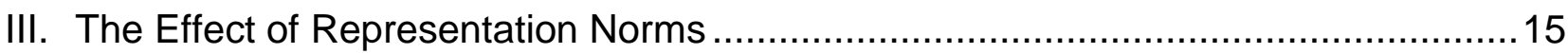

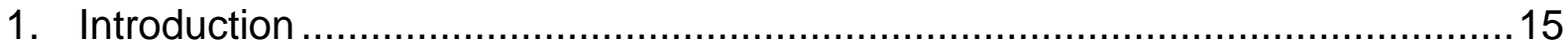

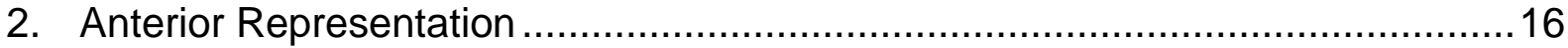

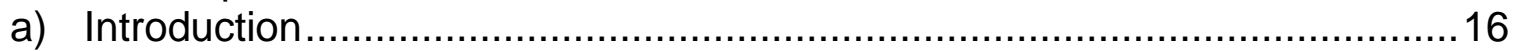

b) Effects on Motivation ...................................................................... 18

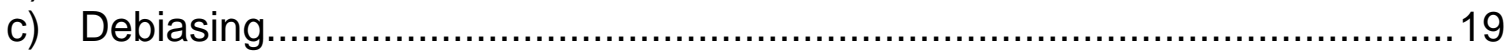

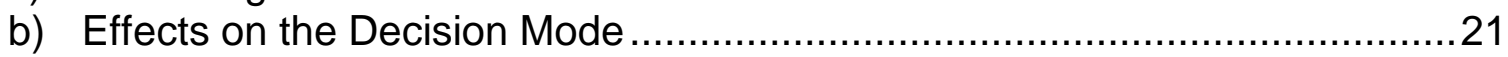

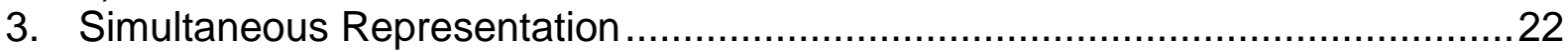

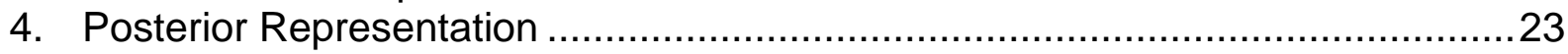

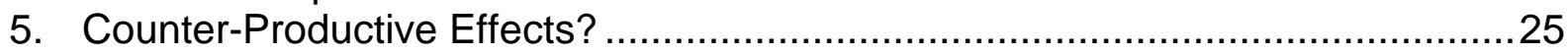

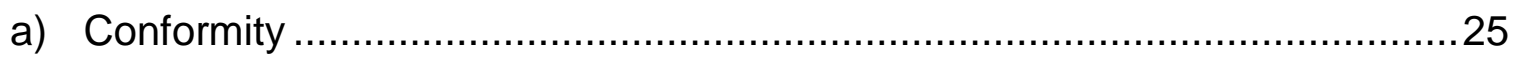

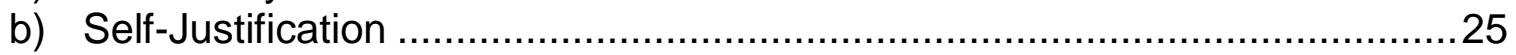

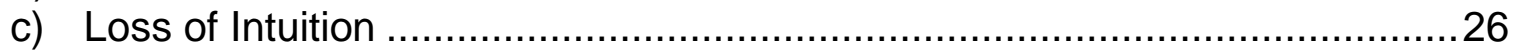

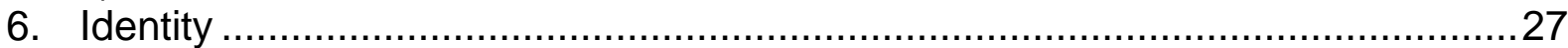

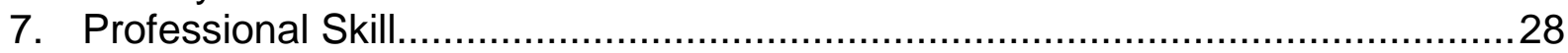

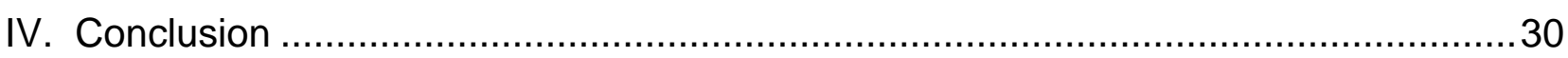

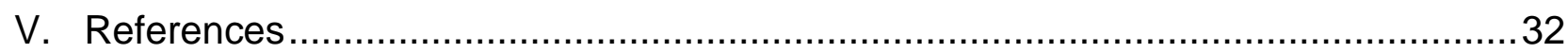

I am grateful to Manfred Aschke, Martin Hellwig and Tom Tyler for helpful comments on an earlier version of this paper, to Lena Heuner for research assistance, and to Darrell Arnold for the linguistic finish. 


\section{Introduction}

Write 500 times: "I must not chat in class". Today's teachers do not consider such orders to be particularly effective pedagogical tools. Is the law more effective if it orders judges to write down why their decisions are justified? For this is, in essence, the claim of this paper: representation norms matter for the quality of judicial decisions. Specifically, the positive effect is traced back to what happens in the judge's mind. Consequently, representation norms have value and should be upheld (section 1). This introduction lays the groundwork. The representation of judicial decisions is not just a mirror of what happened when the judge "made up his mind" (section 2). Representation norms flow from multiple sources (section 3). Their goal is not limited to improving the quality of decisions (section 4). Moreover, the scope of the argument presented here is confined to a standardised set of facts (section 5). There is some reluctance, in doctrine, to formulate explicit norms for the quality of decisions. But such norms are implicit in the institutional framework for judicial decision-making, and in representation norms in particular (section 6).

\section{Normative Starting Point}

German courts write long decisions; the higher the court, the longer the decision. Judgments by the European Court of First Instance frequently run over hundreds of pages. The printed reports of US courts fill entire rooms. Not everybody thinks this is appropriate. Politicians ${ }^{1}$ as well as judges have called for reform. ${ }^{2}$ In the interest of saving money ${ }^{3}$ and of being understandable to the addressees, ${ }^{4}$ they hail short pieces hammering home the basic points. Some scientists second. They do not believe in the positive effect of representation norms on the quality of decisions. ${ }^{5}$ This paper speaks up against such proposals for judicial reform. There may be room for incremental change. But any deregulation of representation norms should take into account that representation norms have positive effects on the quality of decisions.

\section{Autonomy of Representation}

Naïve observers sometimes expect the representation of judicial decisions to mirror the mental process of those generating them. Scientists have long challenged this view. ${ }^{6}$ Representation is an

For a prominent view, see the former Minister of Justice in the State of Saxony, HeITMANN in Neue Juristische Wochenschrift (1997).

BALZER in Neue Juristische Wochenschrift (1995).

Ibid. 2448.

HEITMANN in Neue Juristische Wochenschrift (1997).

TRUTE, in Schmidt-Aßmann and Hoffmann-Riem (2004, 309), asks whether the repercussions of representation norms on the generation of judicial decisions are more than fabulation. RACHLINSKI in Sunstein (2000b, 103) claims that effective procedures for debiasing would be at variance with the rule of law, implying that representation norms are ineffective.

6 LUHMANN Automation (1966) 50 and passim; SIMON Unabhängigkeit (1975) 82; SCHLINK in Staat (1980) 8789; BRINK Entscheidungsbegründung (1999); MORLOK and KÖLBEL in Zeitschrift für Rechtssoziologie (2000); NEUMANN in Rechtstheorie (2001) 255 and passim; KISCHEL Begründung (2003) 11 f. and passim; TRUTE in Schmidt-Aßmann and Hoffmann-Riem (2004) . 
autonomous activity. ${ }^{7}$ An old insight from the philosophy of sciences applies: the context of discovery is to be distinguished from the context of representation. ${ }^{8}$ Legal education and judicial practice have always been sensitive to this. There are two separate representation tools, one for the generation of the decision, and one for the final product. The first is usually called an advisory opinion, the second the judgement. ${ }^{9}$ It is categorically impossible to report, after the fact, how insight has emerged. Likewise, many legal orders want the judge or the jury to be personally convinced of their findings. Only the result, not the generation of such personal involvement, can be reported after the fact. ${ }^{10}$ Put differently, while the judge generates the decision, he must convince himself. In representation, he wants to convince others: the addressees, higher courts, the legal community and the general public. In what is to follow, the term representation should therefore not be misread. The goal is not to get as close as possible to a description of the actual mental process of decision-making. Rather this paper investigates the repercussions on the actual generation of the judicial decision of representation activities driven by different concerns.

\section{Representation Norms}

In all legal orders, there are some explicit, formal rules on the representation of judicial decisions. They, for instance, state which kinds of decisions need not carry reasons, like jury decisions. ${ }^{11}$ Or they stipulate minimum requirements for the quality of representation. ${ }^{12}$ Additional requirements are to be found in doctrine. ${ }^{13}$ Yet for the psychological question investigated here, this would be too narrow a definition of representation norms. ${ }^{14}$ The definition ought to encompass informal rules. With respect to the representation of judicial decisions, these informal rules are detailed.

The starting point is, of course, the syllogism. The ruling must logically follow from the decisive norm, as interpreted in this decision. The court must therefore establish the presence of the facts that are necessary for the decisive norm to apply. It must do so in a logically consistent way. But there is much more to be shown. Are there potential doctrinal objections, and why do they not

$7 \quad$ KISCHEL Begründung (2003) 13; TRUTE in Schmidt-Aßmann and Hoffmann-Riem (2004) 309.

8 POPPER Logik (1935) § 1 I 3, p. 6 f.. In the philosophy of science, there is controversy not about principle, but also about degree. Critics of scientific positivism claim that the autonomy of insight is not absolute. In this perspective, the contents of scientific findings partly result from the process of their generation, and from the personality of those who were engaged in this process. For a prominent view, see ZIMAN Real Science (2000); cf. also DASTON in Bödeker, Reill and Schlumbohm (1999).

9 The German technical terms are more graphic. The first is called Gutachten, the second Urteil.

10 More from SCHULZ Beweistheorie (1992) $\$ 2$.

11 More from SCHAUER in Stanford Law Review (1995) 634: "When juries deliver verdicts, when the Supreme Court denies certiorari, when state supreme courts refuse review, when federal courts of appeal dispose of cases from the bench or without opinion, when trial judges rule on objections and frequently when they rule on motions, when lawyers exercise peremptory challenges and sometimes when judges dismiss jurors for cause, when housing and zoning authorities refuse to grant variances from their regulations, and sometimes when judges impose sentences".

12 An illustrative example is provided by sec. 267 German Code of Criminal Procedure (Strafprozessordnung).

13 See e.g. Bundesverfassungsgericht Jan. 13, 1995, Zeitschrift für Miet- und Raumrecht 1995, 150: if a lower court does not expressly address relevant facts brought forward by one of the parties, this counts as evidence for the court having ignored them. Cf. RAFI Gutes Urteil (2004). 
hold? Has the court heard, understood and properly considered the arguments of the parties? If this is questionable: what shows that the courts was fair in the way it organised procedure? Which of the proofs presented by the parties has the court found to be conclusive, and why? What is, in the court's view, the kernel of the conflict between the parties? If this conflict cannot be fully addressed, which legal rule obliges, or entitles, the court to frame the issue more narrowly? If this is questionable: why has the court treated this case differently than potentially similar cases? If the court has not followed an established line of jurisprudence: does it have sufficiently compelling reasons? Is it able to cite important authorities in support of the change? In oral representation: is the court able to replace doctrinal technicality with a language that the parties are likely to grasp? If journalists are in the court room, or are likely to read the decision later: does the court show an awareness of the political ramifications of the case and the decision? If the decision is likely to be read as an official statement of morality: which moral view is predominant, and why is it legitimate?

Some legal orders, like the German one, even reserve a separate stage of legal education for the purpose of teaching these norms. Young lawyers learn how to write a judgment "in canonical form". ${ }^{15}$ Again, the autonomy of representation plays itself out. In the most general terms, representation norms do not aim at the literal description of the mental process that has led to the decision. Rather representation serves a set of separate goals, one of which is its repercussions on the quality of the decision. In order to qualify as norms, however, a normative expectation must be levied on the individual judge. It usually follows from some kind of informal sanction for infractions. Drawing the exact borderline between informal representation norms and mere representation routines is, however, sometimes not easy.

\section{Concomitant Regulatory Goals}

Improving decision quality is by no means the only purpose of representation norms; neither is it their only effect. ${ }^{16}$ There are many accompanying purposes: one is to clarify the meaning of the verdict. ${ }^{17}$ A second purpose is to officially construct reality. ${ }^{18} \mathrm{~A}$ third goal can be to provide the legal system with one more degree of freedom, in the interest of coping with greater complexity. ${ }^{19}$ The complexity can result from the tension between individual justice and general rules. It can

15 SCHAUER in Stanford Law Review (1995) 633; popular German hornbooks include SCHUSCHKE and DAUBENSPECK Bericht, Gutachten und Urteil (2003); ZIMMERMANN and BERG Klage, Gutachten und Urteil (2003).

16 The distinction between improving decision quality and concomitant goals should not be mistaken. It is not meant to be a value judgement. One might well argue that some of the goals listed below are even more important than decision quality. Decision quality simply is the chosen topic of this paper.

The goals of representation norms are rarely discussed in jurisprudence. An exception is the Bayerischer Verfassungsgerichtshof (Mar. 3, 1991), Neue Juristische Wochenschrift (1991) 2413, 2414.

17 KISCHEL Begründung (2003) 45.

18 This is particularly visible in the burden of proof. It allows the court to decide on an uncertain factual basis. The written version of the decision lays down the version of reality on which the decision is based.

19 LUHMANN Automation (1966) 51 ff; TRUTE in Schmidt-Aßmann and Hoffmann-Riem (2004) 300; see also ENGEL in Rengeling (2001a) on the many competing features of the law as a governance tool. The procedural counterpart of this feature of substantive law is a decision in which several reasons are provided for one and the same decision. 
originate in fundamental normative relativity. ${ }^{20}$ Explicit reasons make it possible to offer justifications on alternative normative grounds, ${ }^{21}$ or to drive a wedge between the decision in favour of one interest, and the wording in favour of the competing interest. ${ }^{22}$ Complexity can also result from a plurality of audiences, like the addressees vs. the legal community. These audiences may be sensitive to different nuances in the reasoning. A fourth purpose is to enable control, ${ }^{23}$ in particular by appellate courts. ${ }^{24}$

A fifth raison d'être of representation norms is their anticipated effects on addressees. ${ }^{25}$ These effects can be manifold. Ordinary addressees are not themselves lawyers. The judge must therefore make them understand what the decision means for them. In cognitive science, this activity has been dubbed compression. ${ }^{26}$ The mechanics of the law are "brought to human scale". ${ }^{27}$ One strand of psychological thinking explains why this is a demanding task. Apparently, people hold fairly firm beliefs about how the human mind works, but these beliefs differ profoundly from the findings of scientific psychology. ${ }^{28}$ Consequently, one task of representation is to present judicial decisions such that they become plausible in terms of folk psychology. Representation can also serve as a tool for removing uncertainty. It can help overcome spurious individual constructions of reality. A particularly likely reason for this is overconfidence, resulting from a self-serving bias. ${ }^{29}$ Also, it is not so rare that the reason for going to court is based in an emotionally laden conflict among the parties, rather than a matter of substance. ${ }^{30}$ In such cases, representation can try to go beyond the legal substance of the case, and aim at restoring peace. Moreover, not all litigants are the same. Psychological research on personality offers many insights into this. ${ }^{31}$ Representation makes it possible to address them individually.

20 More from ENGEL in Rechtstheorie (2001b).

21 This is suggested by SUNSTEIN in Harvard Law Review (1995).

22 Cf. the distinction by BRUNSSON Hypocrisy (1989) between talk, decision and action. See also HÉRITIER Deadlock (1999).

23 SCHAUER in Stanford Law Review (1995) 657; KISCHEL Begründung (2003) 48-52; see also OEHLERS in Neue Juristische Wochenschrift (1994) 713.

24 For an explicit example, see the Bundesverfassungsgericht Feb. 20, 2001, R 53 (unpublished paragraph): "Die verfassungsrechtlich gebotene volle gerichtliche Kontrolle der Annahme von 'Gefahr im Verzug' ist in der Praxis nur möglich, wenn nicht nur das Ergebnis, sondern auch die Grundlagen der Entscheidung der Behörden und ihr Zustandekommen zuverlässig erkennbar werden. Aus Art. 19 Abs. 4 GG ergeben sich daher für die Strafverfolgungsbehörden Dokumentations- und Begründungspflichten, die den wirksamen gerichtlichen Rechtsschutz erst möglich machen (vgl. schon BVerfGE 61, $82<110>$; 69, $1<49>$ ).“

25 Cf. Schauer in Stanford Law Review (1995) 658: "That giving reasons is a way of opening a conversation may in fact be an independent basis for a reason-giving requirement".

26 TURNER Cognitive Dimensions (2001) 26 and passim.

27 Personal communication by MARK TURNER.

28 There is a growing literature on this topic, including MALLE in Journal of Experimental Social Psychology (1997); KASHIMA, MCKINTYRE and CLIFFORD in Asian Journal of Social Psychology (1998); LUPFER, WEEKS, DOAN and Houston in European Journal of Social Psychology (2000); THOMAS Folk Psychologies (2001); KITCHENER in New Ideas in Psychology (2002a); KITCHENER in New Ideas in Psychology (2002b); cf. also STEINER, BOWERS and SARAT in Law and Society Review (1999) (looking at the behaviour of lay judges).

29 BABCOCK and LOEWENSTEIN in Sunstein (2000).

30 More from FARNSWORTH in Sunstein (2000).

31 A particularly pertinent strand of personality psychology is work on sensitivity to injustice; see SCHMITT in Personality and Individual Differences (1996). 
While all the former can be read as services provided by the judicial system to the parties, not so rarely the law has an autonomous interest in representing its decisions well. Otherwise, addressees are less likely to acquiesce. ${ }^{32}$ Psychologically speaking, they show reactance. ${ }^{33}$ Legally speaking, appropriate representation is a way of generating legitimacy in the eyes of the addressees. ${ }^{34}$ This effect of representation has different facets. In the weakest case, the way the case is presented allows the loser to save face. This is a way of preserving self-esteem. ${ }^{35}$ Representation is somewhat stronger if the addressee sees it as an element of procedural fairness. ${ }^{36}$ In the strongest case, the addressee perceives representation as serious discourse. He understands why the applied rules are justified. ${ }^{37}$

This then leads to the sixth purpose of representation norms. They can aim at stressing normativity. Representation in this perspective is meant to remind the individual party in the case that he is a citizen, with the duty to abide by the law. ${ }^{38}$ While the law would in principle be content with obedience, it psychologically is more likely that normativity will have the power to change attitudes, or preferences. This is due to the reduction of cognitive dissonance. ${ }^{39}$ Precisely if the addressees of decisions see the applied legal rules as legitimate, the effect is likely. In such cases, having been in court contributes to learning the law. ${ }^{40}$

A seventh purpose of representation norms is their anticipated effect on professional audiences. The formal audience comprises all higher courts, including the constitutional court. Representation norms see to it that these courts are provided with the necessary information, without being overwhelmed with detail. This function is even more important in a case law system, where earlier cases have the open or hidden force of law. Along with this, there is an informal professional audience, i.e. legal professionals. It is most pronounced in legal orders like the German one, where legal academia and legal practice are closely intertwined. German courts never know whether their decisions will be published and discussed in professional journals. This serves as an additional check, and plays itself out in scholarly components of representation - the more so, the higher the court.

Related to this is an eighth purpose. It is not only the legal community that notices court decisions. So does the public at large. This is particularly likely if a case has attracted media interest. But there are also narrower audiences, like that of a tenants' association in landlord and tenant jurisprudence, or the accidental visitor in the courtroom. In these instances, representation aims at

32 See only KisCHEL Begründung (2003) 52-58. The technical ramification is a higher or lower willingness to appeal (58); BALZER, in Neue Juristische Wochenschrift $(1995,2454)$, is opposed to such "extrajudicial" considerations.

33 The classic text on reactance is BREHM Reactance (1966) ; see also BREHM and BREHM Psychological Reactance (1981); DONNELL, THOMAS and BUBOLTZ in Journal of Social Psychology (2001).

34 SCHARPF Games (1997, 152 f.) links both concepts.

35 Cf. Brennan and PetTit in Economics and Philosophy (2000); BrenNAN and PetTit The Economy of Esteem. An Essay on Civil and Political Society (2004).

36 See TYLER Why People Obey the Law (1990); FREY and BOHNET in Journal of Institutional and Theoretical Economics (1995); FREY and STUTZER Beyond Bentham (2001).

37 More on the discursive character of applying the law in court from ENGEL in Rengeling (2001a).

38 More on the philosophical background from JAKOBS Norm, Person, Gesellschaft (1999)

39 The classic text is FESTINGER Cognitive Dissonance (1957).

40 More on the latter from ENGEL Learning the Law (2004a). 
conveying legitimacy to the judicial system, ${ }^{41}$ and at generating trust in its proper functioning. Representation also contributes to expressing social values, as enshrined in legal rules. ${ }^{42}$

The ninth and final purpose of representation norms is evolutionary. By deciding the case at hand, the legal order learns how to refine, and occasionally also how to alter, the applicable rules. By representing the result in accord with the expectations of the legal professional discourse, the individual decision becomes a tessera in the legal mosaic. ${ }^{43}$

\section{Scope of the Argument}

Three dimensions of the topic are not covered in this paper. Here, there is no distinction being made between judicial tasks. A more encompassing investigation would have to do that. There might be differences between lower and higher courts; between private law, criminal law, administrative law and constitutional law disputes. The representation of final decisions might not be the same as the representation of interim decisions. Arbitration might not be the same as a sovereign decision.

Moreover, although all judges hold the same office, they still have different personalities, and different decision-making and representation styles. Elected judges may behave the same way as appointed judges, in particular if there is a re-election.

Finally, and most importantly from a psychological perspective, this paper only looks at decisions taken by individual judges. This is narrow because many cases are tried by judicial bodies. ${ }^{44}$ In some legal orders, the decision in one and the same case is even split between the professional judge and a jury. ${ }^{45}$ Behaviour of and in such bodies is known to differ significantly from the behaviour of individuals. ${ }^{46}$ Consequently, representation norms should also play themselves out differently.

$41 \quad$ KISCHEL Begründung (2003) 58.

42 The literature on "expressive law" stresses the point; COOTER in Journal of Legal Studies (1998) 585; see also ADLER in University of Pennsylvania Law Review (2000); ANDERSON and PILDES in University of Pennsylvania Law Review (2000); MCADAMS in Virginia Law Review (2000); BOHNET and COOTER Expressive Law (2001).

43 Again, and surprisingly, BALZER in Neue Juristische Wochenschrift (1995, 2451 and 2452) is opposed.

44 On this, see KORNHAUSER in International Review of Law and Economics (1992); KORNHAUSER and SAGE in California Law Review (1993); also see KORNHAUSER in Southern California Law Review (1995); the paper occasionally refers to juries, however, since there are practically no individual lay judges. The jury then stands as a proxy for individual judges.

45 There is a whole literature on decision-making by juries, see only HASTIE, PENROD and PENNINGTON Inside the Jury (1983); HASTIE Inside the Juror (1993).

46 From the rich literature, see only KERR, MACCOUN and KRAMER in Psychological Review (1996). 


\section{Norms for Decision Quality}

This paper claims: representation norms can improve the quality of judicial decisions. Testing this hypothesis presupposes a norm for decision quality. One might expect the legal order to be quite outspoken on this. But actually this is not the case. This stands in sharp contrast to administrative decisions. There, limiting discretionary powers by rules on decision-making procedure is prominent. The administration may not abuse discretionary powers for purposes for which they have not been accorded. It must be aware of its discretionary powers. It may thus not handle the case as if it only had to implement the statutory rule. It must be aware of those facts that arguably could have had an impact on the decision outcome. ${ }^{47}$ Of course, doctrinally speaking, courts normally have no discretionary powers. But due to the hermeneutical character of applying legal rules to facts, judges are not just "la bouche de la loi". ${ }^{48}$ The quality of decisions should therefore matter.

There are indeed some pertinent rules. For instance, procedural codes authorise the recusal of the judge if he appears to be prejudiced against one of the parties. Also, there are strict rules about which evidence may be heard, and who pleads first. But procedural law seems to be rather reticent to govern the quality of decisions, and for good reason. For explicit rules on decision quality would invite the parties to appeal judgments on these grounds. These rules would thus turn into tools for formal control. The lower courts would be disempowered, and the actual decision would eventually be taken by the higher courts. ${ }^{49}$ This is, however, not to say that the law is agnostic with respect to the quality of decisions. But mostly, the normative expectations on decision quality are hidden in the corpus of procedural rules. Representation norms are part of this institutional arrangement. In this reading, representation norms exist precisely because the legal order anticipates that they will have a positive effect on the quality of decisions.

\section{The Psychology of Judicial Decision-Making}

This paper expects representation to have a positive impact on the quality of decisions. Specifically, it expects this effect to be psychological in nature. In order to investigate the issue, this section explores the psychology of judicial decision-making, with an eye to potential normatively relevant problems. There may be three grounds for such problems. A first possibility is straightforward. Sometimes, judges may want to take non-normative decisions. In this case, the problem is motivational (section 1 below). But the problem may also be cognitive. Judges may be affected by biases (section 2). In order to understand the third concern, one must dig deeper. The human mind offers more than one way to take decisions. In the absence of appropriate representation norms, judges might be likely to rely on a normatively questionable decision mode (section 3). These three issues share a normatively relevant property: while there might well be a dispute about

47 For a summary treatment in German law, see MAURER Allgemeines Verwaltungsrecht (2002) § 7.

48 MONTESQUIEU De l'esprit des loix (1748) XI.6.

49 Cf. TRUTE in Schmidt-Aßmann and Hoffmann-Riem (2004) $324 \mathrm{f}$. JOACHIM SchUlZ pointed me to the fact that this is what actually happens in German criminal law. Here, appeal is practically without limits. This has led to a situation where the court of first instance routinely confines itself to some kind of summary assessment. All parties expect the actual decision to be taken by the court of appeals only. 
the norms for decision quality, these three issues are likely to be seen as a problem by almost everybody. Making them less likely will therefore widely been accepted as a desirable outcome.

\section{Motivation}

The legal system has always been the object of suspicion. ${ }^{50}$ Legal realism, ${ }^{51}$ critical legal studies ${ }^{52}$ and law and economics all expect judges to be selfish. ${ }^{53}$ Judges are humans. There must be some motivational forces at work when they take decisions. ${ }^{54}$ But happily, in civilised Western countries corrupt judges seem to be rare. Generally speaking, judges seem to be aware that they are deciding over other people's lives, and that they owe them and society a good deal of respect.

This does, however, not preclude normatively undesirable secondary motivational influences from coming into play. Judges might want to keep their workload reasonable. Some issues might touch upon deep personal convictions of the judge that are at variance with the legal order. Judges might not be able to free themselves from constructions of reality which result from their personal socialisation. The Zeitgeist may play itself out where this is normatively questionable. A judge may want to demonstrate to himself or his peers the brilliance of his professional skills. He may not be free from emotional involvement. Any of these influences may even work at the subconscious level, and therefore be beyond volitional control. ${ }^{55}$

\section{Cognition}

Even if a judge has the most honest of intentions, his decisions can still suffer from the cognitive limitations of the human mind. Under the rule of law, each individual decision matters. Consequently, psychologically speaking, not only systematic bias matters; so does occasional error. Gross outliers are normatively more disquieting than systematic, but negligible deviations from some norm for decision-making. Yet occasional deviations are hard to target with institutional intervention. Institutions inevitably either become too severe, or too general. This explains why, in the design perspective taken here, biases are indeed of greater interest.

50 See e.g. BRECHER in (1958) 231, $246 \mathrm{f}$. and passim.

51 For a summary reference, see FRANK Courts on Trial (1949); contemporary voices are summarised in RUBIN in Harvard Law Review (1996).

52 See only KELMAN Critical Legal Studies (1987) 45-48. Recently, political scientists have also become interested in the matter. See SEgAL and SpaEth Attitudinal Model (1993); QuINN in San Diego Law Review (1996); SEGAL and SPAETH Attitudinal Model Revisited (2002).

53 See MACEY in Journal of Legal Studies (1994, 630-632), for a discussion of judges' "bureaucratic preferences"; POSNER in Supreme Court Economic Review (1993) assumes judges to maximise income, leisure and judicial voting.

54 Critical e.g. judge MCCORMAC in Ohio State Law Journal (1994).

55 The point has already been stressed by CARDOZO The Nature of the Judicial Process (1921) $167 \mathrm{f} ., 174 \mathrm{f}$. and passim. 
Biases are typically defined against the benchmark of rational choice models. ${ }^{56}$ In many contexts, this is a problematic measurement rod. ${ }^{57}$ But judges take decisions on other people's lives, and on behalf of society. For this task, gross deviations from objective rationality will usually also be seen as normatively problematic. If the legal order knew about interventions that could eliminate or reduce these biases, it would want to use them - provided they do not have side-effects that are even more problematic. Specifically, the legal order would see representation as beneficial if it had this effect. It consequently would be willing to shape representation norms accordingly.

It is unlikely that some biases will be found among judges. This is due to the features of the judicial task, and to the heavily institutionalised context within which judicial decisions are taken. An example is loss aversion. ${ }^{58}$ For judges, in their professional role, do not come into situations where they must fear pecuniary loss. Another example is the self-serving bias. Generally, people tend to adhere to a fairness standard that favours their individual strengths. For instance, strong actors tend to think it fair if outcome is proportional to input. ${ }^{59}$ But judges do not assess the fairness of outcomes for themselves. Likewise, people tend to overestimate their individual abilities. Consistently, in tests, individuals rank themselves above average on all kinds of tasks. ${ }^{60}$ But judges do not have to predict the impact of their decisions on themselves. ${ }^{61}$ Yet a good number of other biases are likely to affect judicial decision-making as well. ${ }^{62}$

Judicial bias is to be expected in perception. A first candidate is framing. ${ }^{63}$ If framing is present, the decision output depends on how the case has been presented to the judge, rather than on its merits. ${ }^{64}$ A related bias is anchoring. It affects the assessment of quantitative dimensions. If a subject is asked to assess, in quantitative terms, how far a given judgment object differs from an arbitrary number, the arbitrary number chosen has a strong impact on the assessment. ${ }^{65}$ Accordingly, criminal judges will be influenced by the numbers of years in prison demanded by the attor-

56 For an overview see CONLISK in Journal of Economic Literature (1996).

57 Critical voices are Gigerenzer, TODD and ABC RESEARCH Group Simple Heuristics (1999) (Man must survive in a permanently changing, uncertain environment. Hence adaptivity, not rationality, is the correct benchmark.) KERR, MACCOUN and KRAMER in Psychological Review (1996) 688-690. (Instead of using the absolute benchmark of rational choice, the norm could just as well be taken from comparing individuals or situations).

58 See only Kahneman, KNETSCH and THALER in Kahneman and Tversky (2000).

59 More, from a legal perspective, from FARNSWORTH in University of California at Davis Law Review (2003).

60 Classic SVENSON in Acta Psychologica (1981); from a legal perspective see BABCOCK and LOEWENSTEIN in Sunstein (2000).

61 This is overlooked by GUTHRIE, RACHLINSKI and WISTRICH in Cornell Law Review (2001) 811-816. Their experimental test is inappropriate in that it does not test for the impact of self-serving bias on judicial decisionmaking.

62 See RACHLINSKI in Oregon Law Review (2000a); GUTHRIE, RACHLINSKI and Wistrich in Cornell Law Review (2001).

63 Kelman, RotTenstreich and TVERsky in Sunstein (2000); MCCAFFERy, Kahneman and SPITZER in Sunstein (2000); RACHLINSKI in Oregon Law Review (2000a) 96-99; GUTHRIE, RACHLINSKI and WISTRICH in Cornell Law Review (2001) 794-799.

64 Classic texts on framing are: TVERSKY and KAHNEMAN in Science (1981); KAHNEMAN and TVERSKY in Kahneman and Tversky (2000).

65 See only TVERSKY and KAHNEMAN in Science (1974); STRACK and MuSSWEILER in Journal of Personality and Social Psychology (1997). 
ney general. ${ }^{66}$ Judges are also likely to be biased by representativeness. ${ }^{67}$ This implies that judges will often jump on the most representative features of the case at hand, and might overlook how it deviates from a standard situation. ${ }^{68}$ They also might neglect what they know, or what they might learn, about the general probability of the event in question, the base-rate. ${ }^{69}$ Judges may suffer from the fundamental attribution error. ${ }^{70}$ If they do, they tend to wrongly attribute outcomes to human action, rather than to features of the situation. ${ }^{71}$

Biases also affect actual judgment. A well-documented instance of this is the hindsight bias. ${ }^{72}$ An example is torts. In most legal orders, the relevant test calls for an assessment ex ante: could the tortfeasor have been expected to anticipate the risk and to take precautions? Yet, of course, when the case is in court, the victim has suffered damage. Psychologically, it is next to impossible to ignore this ex-post knowledge. ${ }^{73}$

\section{Decision Mode}

In the concept of biases, one deviation from a norm for decision-making is isolated. Representation norms are an effective tool if they can be demonstrated to eradicate, or at least reduce, this one bias. As will be shown further below, there is value in this approach. But representation norms are rather sweeping. This makes it advisable to look out for more general effects as well. They can indeed be found in the meta-choice between decision modes. ${ }^{74}$ The question calls for a thought experiment. What would judicial decision-making be like in the absence of representation norms? The answer comes in two steps: the judicial task must be defined in psychological terms (section a below), and the likely decision mode for this kind of task must be found (section b).

66 ENGLICH and MUSSWEILER in Journal of Applied Social Psychology (2001); more on anchoring in judges from HINSZ and INDAHL in Journal of Applied Social Psychology (1995); RACHLINSKI in Oregon Law Review (2000a) 96-99; GUTHRIE, RACHLINSKI and WISTRICH in Cornell Law Review (2001) 787-794.

67 VON WINTERFELDT and EDWARDS in Southern California Law Review (1986); KoEHLER in Cornell Law Review (1990); RACHLINSKI in Oregon Law Review (2000a) 82-93; GUTHRIE, RACHLINSKI and WISTRICH in Cornell Law Review (2001) 805-811.

68 The classic text is TVERSKY and KAHNEMAN in Kahneman, Slovic and Tversky (1982). A shorthand way of expressing the problem is: subjects are likely to judge by way of analogy, even where the analogy is misleading, NOLL and KRIER in Sunstein (2000) 330.

69 RACHLINSKI in Oregon Law Review (2000a) 82-93; see also KoEHLER in Engel and Gigerenzer (2005) on the biased handling of statistical information, of which base rate neglect is but one instance.

70 RACHLINSKI in Engel and Gigerenzer (2005) ***4 f. of pdf.

71 Classic texts are Nisbett, CAPUTO, LEgAnt and MARECEK in Journal of Personality and Social Psychology (1976); Ross in Berkowitz (1976).

72 LABINE and LABINE in Law and Human Behavior. (1996); STALLARD and WORTHINGTON in Law and Human Behavior (1998); HASTIE, SCHKADE and PAYNE in Law and Human Behavior. (1999); RACHLINSKI in Sunstein (2000b); RACHLINSKI in Oregon Law Review (2000a); GUTHRIE, RACHLINSKI and WISTRICH in Cornell Law Review (2001) 799-805.

73 The effect has first been demonstrated by FISCHHOFF in Journal of Experimental Psychology: Human Perception \& Performance (1975); for further background also see HAWKINS and HASTIE in Psychological Bulletin (1990); RACHLINSKI in Sunstein (2000b) $97 \mathrm{f}$.

74 Although he does not use this psychological terminology, MCCORMAC, in Ohio State Law Journal (1994), comes close to this when he calls for "reasoned decision-making", rather than "result-based decision-making". 


\section{a) Task Construal}

Psychological findings are normally generated in experiments. This method allows for a high degree of objectivity. But the price for objectivity is decontextualisation. Experimental tasks tend to be fairly simple and standardised. One of these standardisations is the distinction between decision tasks and judgment tasks. ${ }^{75}$ Judicial decision-making is more complex and does therefore not easily fit into simple conceptual boxes. One conceptual strategy consists of splitting up the judicial task into a sequence of standard tasks. ${ }^{76}$ Yet this approach inevitably neglects what seems obvious in judicial practice: the individual preparatory steps, like the hearing of witnesses, are part and parcel of one-integer judicial task.

The mere term "judge" rather clearly suggests that judges have a judgment task. It indeed obviously has a pronounced judgmental component. The judge (or the jury) must find out whether the defendant has committed the crime for which he is accused, and whether he has intended to do so. Similar judgmental components are to be found in private or administrative law suits. But the judicial output is routinely referred to as a "decision". ${ }^{77}$ Legal terminology thus hints at the fact that the judicial task oscillates between judgment and decision-making. In criminal procedure, for instance, the judge's task is not confined to an assessment of the facts. Based on his assessment, a continental European judge convicts the defendant. In U.S. law, this is the judge's task, while it is up to the jury to assess the facts. But no jury sees this as an academic exercise. It knows that the defendant will be convicted if the jury finds him guilty.

Yet this is no ordinary decision. Judge and jury know that the main effect of their decision is on other people's lives. There may occasionally be personal side-effects, like a bad press. But judicial decision-makers are aware that the main effect is on others. They can thus be viewed as taking a decision stripped of intent. ${ }^{78}$

Actually, the judicial output is a mere utterance. Its direct effect on the parties is at most reputational. The main effect is indirect. Based on this utterance, the executive branch of government puts the defendant in jail, forces him to pay damages, or puts his child in custody. Usually, defendants anticipate the power of government to bring all this about. The mere threat of enforcement is enough to change the defendant's behaviour. All this is so obvious to the judge that he acts as if he indeed executed his decision himself.

At closer sight, categorising the judicial task in psychological terms is even more demanding. Judges and jury members do not only have a decision object that is foreign to them. They also rely on foreign decision authority. It is conveyed to them by government. This distinguishes judges

\footnotetext{
75 More from GOLDSTEIN and HOGARTH Judgement (1997b).

76 Hastie, Penrod and Pennington Inside the Jury (1983) 15-22; Hastie Inside the Juror (1993) $192,201$.

77 Doctrinally, this also holds in the exceptional cases where the decision is confined to a statement of fact or law. For this statement becomes binding among the parties.

78 To be sure, in an epistemologically informed perspective, even a simple exercise in generating meaning is not devoid of subjectivity, and hence it has a decisional element; see only ALBERT Kritische Praxis (1978). But this is not the kind of decision that is meant by the psychological concept of a decision task.
} 
from representatives, who render the parties a service for which they have asked. Put differently, judges do not just play a role. They hold an office. ${ }^{79}$

Government does not endow judges with unfettered powers. It is their task to apply an abstract legal rule to the concrete case. Time and again theorists and politicians have denied that there is a decision-making component in this activity at all. ${ }^{80}$ But this is not a mechanical activity. It is hermeneutical. Hermeneutical tasks cannot be executed without personal involvement. ${ }^{81}$ And again, judicial decisions are specific. In other hermeneutical tasks, the task is confined to generating meaning. In the judicial interpretation of code, however, meaning is generated in the interest of basing a decision on it. Put differently, code is a specific kind of text. It has the force of law. Consequently, understanding the hermeneutical character of the judicial task is yet another way of saying why, psychologically, it oscillates between a judgment and a decision task.

\section{b) Choice of Decision Mode}

How do judges mentally go about this task? This is a meaningful question, since the mind is not a general-purpose computer. While psychologists agree on this level of generality, there is lively controversy about detail. Dual process theorists claim that the human mind has two cabinets. The first, called system one, is a mixed bag of ready-made behavioural rules. I want some more coffee and grab the mug in front of me without further ado. The second cabinet, called system two, is reserved for conscious, elaborate mental action. I go a long way mentally before writing down the first sentence of my next article. ${ }^{82}$ Others distinguish between a reflective and impulsive system. In their view, the borderline between both systems is not watertight. There is the possibility of behaviour without previous reflection. But reflection is not thought to be free from impulses. Instead, reflection is modelled as tightly interacting with impulses. ${ }^{83}$ Yet another group of scholars denies the special role of reflection. These researchers rather see the mind as an adaptive toolbox. ${ }^{84}$ Depending on the situation, people pick an appropriate tool from this box. ${ }^{85}$

This paper is not the right context for attempting to resolve this controversy. Rather, the more specific implications for judicial decision-making should be pointed out. Occasionally, judges might rely on radically simplified decision-making tools. ${ }^{86}$ Highly experienced judges sometimes do this when taking standard decisions. ${ }^{87}$ But mostly, judges will deploy much more mental effort. They know that their decision is important. This generally induces people to use a more effortful

79 More on the conceptual and historical background from SCHUPPERT Staatswissenschaft (2003) 107-153.

80 The most prominent voice is again MONTESQUIEU De l'esprit des loix (1748) XI.6.

81 More from MANTZAVINOS Hermeneutische Irrwege und Auswege (2004).

82 For a classic treatment, see STANOVICH and WEST in Behavioral and Brain Sciences (2000); see the comments published thereafter for a critical discussion; see also EVANS and OVER in Psychologist (1997); CHAIKEN and TROPE Dual Process (1999); BOHNER in Hewstone and Stroebe (2001).

83 STRACK and DEUTSCH Reflective and Impulsive (2002a).

84 This term is used by GIGERENZER, TODD and ABC RESEARCH GrouP Simple Heuristics (1999) 141 and passim.

85 Other researchers from the school include PAYNE, BETTMAN and JOHNSON in Journal of Experimental Psychology (1988); BLAIS and WEBER in Risk Decision and Policy (2001).

86 For a model of such decision-making see ENGEL Social Dilemmas (2004b).

87 Cf. PENNINGTON and HASTIE in Goldstein and Hogarth (1997) 477. 
decision mode. ${ }^{88}$ This is not, however, to say that judges simply follow the norms of rational choice analysis. ${ }^{89}$ Experimental work demonstrates that even conscious decision-making largely deviates from rational choice norms.

One empirically validated option is reason-based choice. ${ }^{90}$ The basic idea is the following: rather than going through all the evidence and carefully weighing the pros and cons, the individual searches for one convincing reason only. Put differently, the driving force is not decision quality, but justification. The likely effect is a limited search. The individual stops searching once he has traced the first sufficiently convincing reason. Ex-ante knowledge about the context guides search in the most promising directions. The implications for judicial decisions are obvious. Since judges do decide on other people's lives, and since they are the agents of government, reason-based choice should be attractive. The limitations inherent in this decision mode should be a true concern for the designer of judicial institutions.

An alternative option is narrative reasoning. ${ }^{91}$ Subjects make up their minds by constructing a plausible narrative. In order to do so, they rely on what they already know about the world. If several such narratives come to their minds, they go for the most convincing one. If they have to decide under uncertainty, they use this method to fill in the gaps. If they have to assess the impact of their decision on future events, they construct a scenario and decide whether this is what they want. Again, the relevance for judicial decisions is patent. ${ }^{92}$ Judges are naturally faced with potentially incomplete evidence. They are likely to organise this evidence in a narrative, even if, for a neutral observer, other constructions would have been equally or more plausible. ${ }^{93}$

Both these options are likely in judicial decision-making. But they are not an exhaustive description of deliberate mental processes. A modularity hypothesis is more appropriate. ${ }^{94}$ Depending on the perceived character of the task, on personal and emotional involvement and potentially on many other factors, the individual has recourse to more mental resources or fewer of them. He may actively search for more facts, or he may just rely on pre-attentive sensory input. ${ }^{95}$ The individual may use heuristics to focus his attention, ${ }^{96}$ perception $^{97}$ and judgement, ${ }^{98}$ or he may go through all of these mental steps by consciously screening and weighing the available information. He may actively search his memory for more information, or just rely on the visible evidence. He

88 PAYNE, BETTMAN and JOHNSON in Goldstein and Hogarth (1997).

89 GOLDSTEIN and WEBER in Goldstein and Hogarth (1997) $590 \mathrm{f}$.

90 SHAFIR, SIMONSON and TVERSKY in Kahneman and Tversky (2000); see also SCHLICHT Custom (1998) 122, 126.

91 For a classic treatment, see BRUNER Actual Minds, Possible Worlds (1986); BRUNER Acts of Meaning (1990); see also PENNINGTON and HASTIE in Goldstein and Hogarth (1997).

92 It is fleshed out by PENNINGTON and HASTIE in Hastie (1993).

93 Ibid. in $198 \mathrm{f}$. offer a formal model for this; STANOVICH and WEST in Behavioral and Brain Sciences (2000) 661 refers to this as the "fundamental computational bias".

94 This idea is in the proximity of STRACK and DEUTSCH Reflective and Impulsive (2002a).

95 On the latter, see e.g. LEWIS in Behavioral and Brain Sciences (2004) ***12 of pdf.

96 Hogarth, GIBBS, McKenZIE and MARQuis in Goldstein and Hogarth (1997) $259 \mathrm{f}$.

97 LEVINSON in Goody (1995).

98 NISBETT and ROSS Inference (1980) 17-42. 
may try to find creative solutions, stick to the traditional set of solutions, or just do what first came to mind.

Not all of these modules are of equal importance for judicial decision-making. Attention to the decision-making task as such is obvious when there is institutional intervention. The judge is presented with an action and has to open the procedure. Since this is in the interest of the parties, they will normally also be careful to bring the relevant information to the judge's attention. Moreover, the activity of the parties is not confined to presenting the facts of the case. They also offer interpretations. Typically, they will be at least partly in disagreement, which is why the judge hears several versions of the case. This will normally force him to actively elaborate on the information presented to him. None of this, however, predetermines the mental mechanism by which the judge generates the ultimate judgment. Some feature of the case may trigger a judgmental heuristic. The judge may rely on associations. ${ }^{99}$ Or he may engage in analytic decision-making. ${ }^{100}$

None of this necessarily poses a normative problem. Eventually, decision quality is a matter of the outcome, not of the mental process for generating it. But some modules may be more error prone than others. Specifically, the rule of law is not content with good average performance. It wants to do justice to the parties of each and every individual case. What would be acceptable, if not desirable, in other decision tasks can therefore be problematic in the courtroom. Consequently, the law should not be opposed to mental shortcuts and to intuition. But it should want judges to double check with more elaborate mental tools before they take the final decision. Of course, psychologically, this ideal may not always be within reach. The intuitively achieved result may blur later attempts at reconstructing the decision-making process in a more elaborate form. Or elaboration may block access to more reliable intuitive mental tools. In such instances, ideal institutional interventions should strike a balance between better outcomes on average and the increased probability of a mistake in exceptional cases.

\section{The Effect of Representation Norms}

\section{Introduction}

Do representation norms improve the quality of decisions? The foregoing allows us to ask three more specific questions: do representation norms have an impact on judicial motivation? Do they serve as a debiasing tool? Do they induce judges to rely on a (more) appropriate decision mode? The few academic observers who have looked into the matter are mildly optimistic. Some believe in "the decision-disciplining function of giving reasons". ${ }^{101}$ Since representation norms are institu-

99 GOLDSTEIN and WEBER in Goldstein and Hogarth (1997) 595; for a formal treatment see BUSEMEYER and TOWNSEND in Psychological Review (1993).

100 GOLDSTEIN and WEBER in Goldstein and Hogarth (1997) 596.

101 SCHAUER in Stanford Law Review (1995) 657, see also 633 f.; further, see QUINN in San Diego Law Review (1996) 703: it is much more difficult to predict decisions of lower courts by measuring non-legal attitudes, compared to the Supreme Court. One explanation for this is in the greater role of doctrine in these decisions, due to the fact that these decisions are open to appeal. 
tions, the general "strong intuition [that the] thickness of institutional veils is important" should apply. ${ }^{102}$ More specifically, representation norms are tools for holding judges accountable. For they oblige judges to justify their beliefs and actions to the parties, to the higher courts, to the legal community and to the public at large. ${ }^{103}$ Psychological research on accountability demonstrates that accountability does not always improve decision quality. But under appropriate framework conditions it does. ${ }^{104}$ In the following, it will be shown that the judicial process is a rather favourable framework for accountability.

In a psychological perspective, not all instances of representation are alike. The decisive feature is timing. Not so rarely, in judicial practice, representation occurs even before the final decision is taken (section 2 below). Oral representation tends to be on the spot, or (almost) simultaneous with decision-making (section 3). Written representation, however, usually comes quite some time after the decision has been taken and promulgated (section 4). To different degrees, and by different mechanisms, these forms of representation may have a beneficial effect on the quality of decisions. There is, however, also the opposite possibility. Psychological research on accountability demonstrates that it can, in principle, be counterproductive (section 5). All of these are short-term effects. The more profound effect of representation norms, however, is long-term. It plays itself out in judicial identity (section 6) and in progressive expertisation (section7).

\section{Anterior Representation}

\section{a) Introduction}

In the legal literature, representation norms are expected to have a beneficial effect on the quality of decisions by way of "judicial self-control". ${ }^{105}$ They force judges to bring their initial intuition in line with doctrine ${ }^{106}$ and make them see to internal coherence. ${ }^{107}$ They remind them of aspects of the case or of the applicable rules they ought not to overlook, ${ }^{108}$ and they caution them about normatively critical features. ${ }^{109}$

Is this more than wishful thinking? From a psychological perspective, one should expect the effect of representation norms to be strongest if representation precedes the final decision. For then representation need not be anticipated; it can have a direct impact on the actual decision-making.

102 CAMERER in Kagel and Roth (1995) 587; this is, however, not a text on judicial decision-making specifically.

103 Cf. the definition of accountability given by LERNER and TETLOCK in Psychological Bulletin (1999) 255; see also the more encompassing definition by SIEGEL-JACOBS and YATES in Organizational Behavior and Human Decision Processes (1996) 1.

104 See, for the moment, only TETLOCK in Social Psychology Quarterly (1985a); TETLOCK in Research in Organizational Behaviour (1985b); TETLOCK in Thompson, Levine and Messick (1999).

105 SCHUMANN in Neue Juristische Wochenschrift (1993) 2788; KISCHEL Begründung (2003) 40-45, see also 13 f.; again, amazingly, BALZER in Neue Juristische Wochenschrift (1995) 2451 is opposed.

106 KISCHEL Begründung (2003) 41.

107 Ibid. $43 \mathrm{f}$.

108 SCHUMANN in Neue Juristische Wochenschrift (1993) 2788.

109 KISCHEL Begründung (2003) 42; see also MCCORMAC in Ohio State Law Journal (1994). 
Such interim representation does indeed occur. ${ }^{110}$ In complex cases, it will be next to impossible for judges and jury members to remember all the evidence. They must take notes, and they will organise them before taking their decision. ${ }^{111}$ In such cases the final decision is reached by iterating tentative representations and equally tentative conclusions. ${ }^{112}$ When they decide which evidence may be introduced, they must know whether it is relevant for the final decision. This interim decision presupposes a provisional assessment of the final outcome. ${ }^{113}$ Not so rarely, elements of interim representation are even communicated to the parties. In that case, the parties can react to representation even before the actual decision is taken. In (German) criminal procedure, the judge is obliged to inform the defendant if he considers the case to be a crime of which he had not formally been accused initially. ${ }^{114}$ Practically, interim representation is most comprehensive if the judge suggests a settlement. He then informs the parties about the likely outcome of the case, or at least about the expected probabilities of losing or winning.

Representation norms can target interim representation in two ways. They can directly address this instance of representation. There are, for instance, informal rules about what a judge should and should not say when suggesting a settlement. These rules attempt to maintain the fine balance necessary to avoid spurring compromise, on the one hand, and to avoid appearing partial, on the other. The more important effect of representation norms, however, is indirect. In interim representation, judges are influenced by the norms for final representation. There are two explanations for this. Ad hoc, judges anticipate that they will eventually have to follow the norms for final representation. This has an impact on task construal. Interim representation is seen as a way of preparing not only for taking the final decision, but also for officially representing it in accordance with prevailing representation norms. Psychologically, it might be easier to anticipate later representation in an earlier representation than to anticipate representation when a judge just privately takes the actual decision, if you will, in the confines of his own mind. A second effect of interim representation on the quality of decisions is via learning. ${ }^{115}$ Over time, representation norms become so natural to judges that they also follow them in interim representation. One may also call this a ritualising effect. ${ }^{116}$

Normatively, judicial decisions can suffer from three behavioural defects: illegitimate motivation (section b below), biases (section c) and an inappropriate decision mode (section d). Does interim representation, as affected by representation norms, have a beneficial effect on these?

\footnotetext{
110 KISCHEL Begründung (2003) 13: typically, judicial decision-making is a dialogue between the mental process and the preparation of representation.

111 U.S. juries, however, are instructed not to do so; for a sceptical view, see HASTIE, PENROD and PENNINGTON Inside the Jury (1983) 18.

112 Judge MANFRED AsCHKE pointed me to this.

113 In German private law, there is a large set of informal rules for the purpose, known as "Relationstechnik", more from ZIMMERMANN and BERG Klage, Gutachten und Urteil (2003). Note that interim representation is paramount for the decision-making in judicial bodies. Typically one judge is appointed as referee for the case. $\S 265$ I Strafprozessordnung (code of criminal procedure).

115 More on this below 7.

116 MARTIN HELLWIG suggested this graphic wording.
} 


\section{b) Effects on Motivation}

The prime legal concern here is partial judges. Accompanying this, there is a concern that judges will be influenced by normatively unacceptable secondary factors, like laziness. Do representation norms help contain these risks? The answer is straightforwardly yes in situations in which the illegitimate reason is the only possible explanation for the outcome. ${ }^{117}$ But in legal practice, this is a rare event. Skilled lawyers will normally be able to find an alternative justification that is in line with legal doctrine. This is due to the inevitable complexity of the legal system. Judges could taint the facts, or they could swap one doctrinal classification for another. ${ }^{118}$

Absolute protection against this is impossible. But representation norms oblige judges to give explicit reasons. They are thus forced to disguise their true motives, and to make up a justification that is in line with doctrine. Psychologically, this creates cognitive dissonance. ${ }^{119}$ To use a term from criminal law: due to representation norms, a judge needs stronger criminal energy to take a decision on illegitimate grounds. The theory of cognitive dissonance predicts that he would prefer to change his attitude.

A further effect can be explained in the terms of the influential AJZEN/FISHBEIN model of reasoned action. ${ }^{120}$ Representation norms require that the judge give reasons that are in line with official doctrine. The activity of providing reasons should therefore influence the salience of social and professional judicial norms. If their personal attitudes are at variance with these norms, judges become aware of the conflict, and they are likely to skirt the conflict by doing what they are expected to do. This reaction should be even more common for them than for ordinary decisionmakers. For judicial decisions affect other peoples' lives. Moreover, judges do not decide on behalf of themselves, but on behalf of the society that has endowed them with the office.

It can be expected that self-esteem will have an additional effect. ${ }^{121}$ Searching for a justification in line with official doctrine makes the deviation from role expectations patent. Judges would have to admit to themselves that they are violating professional duty. As long as judges do not base their personal norms on entirely different sources than the law - say on their religion - sensing a patent deviation from role expectations should have a negative effect on self-esteem. They should feel the urge to restore their self-esteem by bringing their behaviour back in line with duty.

Moreover, people typically do not only care about self-esteem, but also about "other-esteem", or about their impression on others. ${ }^{122}$ Modern psychology speaks about impression management. ${ }^{123}$ People do not only want to avoid being seen as corrupt. They already strongly dislike appearing

117 SCHAUER in Stanford Law Review (1995) $657 \mathrm{f}$.

118 BRECHER in (1958).

119 See, again, FESTINGER Cognitive Dissonance (1957).

120 AJZEN and FISHBEIN Understanding Attitudes (1980).

121 See again BRENNAN and PETTIT in Economics and Philosophy (2000).

122 The relationship between self-esteem and other-esteem is central in SMITH Moral Sentiments (1790) I.ii.V and passim.

123 BAUMEISTER in Psychological Bulletin (1982). 
foolish in front of others. ${ }^{124}$ Representation norms exploit both effects. They do not only induce judges to avoid any suspicion of selfish or otherwise illegitimate bias. They also induce them to strive for a final product that meets high professional standards. This will make them shy away from shallow reasoning, and therefore increase the potential conflict between representation and their original intentions.

The rectifying effect of representation norms should be even stronger if the judge originally wanted to follow his gut feelings. For accountability has been demonstrated to decrease the influence of incidental affect. ${ }^{125}$ It increases the motivation "to get it right". ${ }^{126}$

\section{c) Debiasing}

Do representation norms also have a positive effect on cognition? Are they thus likely to serve as a tool for debiasing? ${ }^{127}$ According to what is known about the mechanics of debiasing, this could be the case. The effect of representation according to professional norms could be direct or indirect. The direct effect is itself cognitive. In accord with the representation norm, for instance, the judge ought to take additional information into account. ${ }^{128}$ This forces the judge to take the whole picture into purview, rather than just one biased perspective. The indirect effect is motivational. Representation norms contribute to holding the judge accountable for the quality of his decision. Falling prey to a bias poses greater risks for his self-esteem, reputation and career. Higher stakes do not always improve the quality of decisions. ${ }^{129}$ But they do if self-critical attention to the judgement process overcomes a bias. ${ }^{130}$ Higher motivation can make people prepare more intensely, ${ }^{131}$ be more open to facts, ${ }^{132}$ take more of the available information into account ${ }^{133}$ and show greater internal consistency. ${ }^{134}$

What does all this mean for individual biases? Representation norms oblige the judge to demonstrate how his decision is derived from the wording of statutory provisions, or from precedent.

124 LERNER and TETLOCK in Psychological Bulletin (1999) 263; see also SIEGEL-JACOBS and YATES in Organizational Behavior and Human Decision Processes (1996) 1.

125 LERNER, GOLDBERG and TETLOCK in Personality and Social Psychology Bulletin (1998).

126 Accountability researchers speak of the "motivational induction on judgment", LERNER and TETLOCK in Psychological Bulletin (1999) 259; they argue it is based either on drive, HuLl Principles (1943); SPENCE Behavior Theory (1956), or on social facilitation, ZAJONC in Science (1965).

127 This is the expectation of SCHAUER in Stanford Law Review (1995) 657; see also RACHLINSKI in Oregon Law Review (2000a) 87 for representativeness bias specifically. For a summary account of the debiasing literature, see CONLISK in Journal of Economic Literature (1996) 671.

128 Cf. TETLOCK in Social Psychology Quarterly (1983b); TETLOCK and BoETTGER in Journal of Personality and Social Psychology (1989).

129 More below 5; too simple FREY and EICHENBERGER in Journal of Economic Behavior and Organization (1994) 225.

130 ARKES in Psychological Bulletin (1991); LERNER and TETLOCK in Psychological Bulletin (1999) 263.

131 TETLOCK in Journal of Personality and Social Psychology (1983a); LERNER and TETLOCK in Ramachandran (1994).

132 Lerner, Goldberg and Tetlock in Personality and Social Psychology Bulletin (1998).

133 TETLOCK in Social Psychology Quarterly (1983b); TETLOCK and BOETTGER in Journal of Personality and Social Psychology (1989).

134 HAgAFORS and BREHMER in Organizational Behavior and Human Decision Processes (1983); ASHTON in Organizational Behavior and Human Decision Processes (1992). 
This puts his decision in a neutral frame. It is likely to differ from the frames of the parties. Specifically, in state-of-the-art representation, the judge must bridge the gap between abstract legal rules and the concrete case. Moreover, he is obliged to respond to the arguments of both parties. This lets him naturally see the case in a different light. For all of these reasons, representation norms will at least attenuate framing effects, if not wipe them out altogether. ${ }^{135}$

Similar considerations apply to anchoring. If the anchor is relevant for the decision outcome, both parties are likely to offer competing anchors. Representation norms oblige the judge to respond to both of them. ${ }^{136}$ A motivational effect is added to this. Representation norms contribute to making the judge aware of the importance of his decision. This makes it less likely that he will jump on the first anchor. ${ }^{137}$ The debiasing effect on anchoring is, however, less pronounced. Anchoring is much harder to overcome by training than framing generally. ${ }^{138}$ Also, in line with the saying "iudex non calculat", the doctrine does not normally provide the judge with quantitative information that could serve as a counter-anchor.

The prediction for debiasing representativeness is better. ${ }^{139}$ Representation norms oblige the judge to say in abstract terms why the case is to be decided one way and not the other. Representation norms do thus serve as tools for decontextualisation. Moreover, in accord with representation norms, it is desirable that the judge present his decision as part and parcel of a line of jurisprudence. Typically, such a line of jurisprudence is not confined to one area of application. Rather, one and the same abstract principle plays itself out in many different contexts. In demonstrating this, the judge becomes aware of the underlying abstract problem, rather than of the salient contextual features of the case.

Base rate neglect is a trickier issue. ${ }^{140}$ Generally speaking, accountability is not instrumental for debiasing if the subject lacks the necessary knowledge or training. ${ }^{141}$ The research on base rate neglect demonstrates that it is pervasive in individuals without statistical training. ${ }^{142}$ Most judges are statistical laypersons. But cases are usually not presented to them in pure numerical form. Specifically, in accord with representation norms it is desirable that they address the contextual features of the case. This can, but need not, naturally induce them to view the concrete case from

135 Cf. TetLock in Social Psychology Quarterly (1983b); TetLock, SkitKA and BoetTGer in Journal of Personality and Social Psychology (1989) 632.

136 Cf. KRUGLANSKI and FREUND in Journal of Experimental Social Psychology (1983).

137 SIMONSON and NYE in Organizational Behavior and Human Decision Processes (1992); SIMONSON and STAW in Journal of Applied Psychology (1992).

138 STRACK and MUSSWEILER in Journal of Personality and Social Psychology (1997).

139 RACHLINSKI in Oregon Law Review (2000a) 87; see also LERNER and TETLOCK, in Psychological Bulletin $(1999,263)$, on the general effect of accountability: subjects are more likely to take situational attributions into account.

140 Cf. SIMONSON and NYE in Organizational Behavior and Human Decision Processes (1992).

141 Wegener and PetTy in Journal of Personality and Social Psychology (1995); KeRR, MACCOUn and Kramer in Psychological Review (1996).

142 KAHNEman and TVERSKY in Cognitive Psychology (1972); see however FIEDLER in Psychological Review (2000) 665 . 
the perspective of the class of cases to which it belongs. This is what base rate information is about. $^{143}$

One might expect judges to be particularly liable to the fundamental attribution error. For after all, the judicial business is all about attributing outcomes to actors. But, from a psychological perspective, evidentiary rules can be interpreted as tools for deciphering personal from situational reasons. Judges are trained to find out whether there is enough evidence to justifiably attribute causality or intent, or whether an event was just happenstance. Representation norms oblige them to explain whether the evidence was conclusive or not. In this way, they contribute to combating the fundamental attribution error. ${ }^{144}$

The hindsight bias is a very robust phenomenon. ${ }^{145}$ Representation norms will therefore not cause judges to forget what they have learned by examining the evidence: the possible event has indeed happened. ${ }^{146}$ But representation norms oblige them to put the individual case into perspective. A decision to hold the defendant liable must be in line with the decisions of other courts in comparable cases. In principle, this should have a certain debiasing effect. It should, however, not be overstated. The hindsight bias in judges creates a normative problem since it induces them to to make rules increasingly stringent. ${ }^{147}$ This tendency is not only due to biased individual decisions. It also rests on a selection effect. Cases only go to court if damage indeed has occurred. If, due to this effect, the entire line of jurisprudence is biased, representation norms are unable to improve the situation.

\section{b) Effects on the Decision Mode}

A first effect of interim representation on decision quality is indirect. It can induce the judge to prepare the final decision more carefully, ${ }^{148}$ e.g. to take more information into account ${ }^{149}$ and search for counterarguments brought forward by the opposing party. ${ }^{150}$ In this respect, interim representation is particularly effective. Both institutional and psychological barriers to the introduction of further evidence into procedure are still low. By the way a judge asks questions, he can

143 Besides, whether base rate information may be taken into account at all, and how much weight should be placed on it is a normative matter.

144 Cf. TETLOCK in Social Psychology Quarterly (1985a).

145 FISCHHOFF in Journal of Experimental Psychology (1977); DAVIES in Organizational Behavior and Human Decision Processes (1987).

146 This also explains why competing stories told by the defendant's attorney do not have a strong effect; more from STALLARD and WORTHINGTON in Law and Human Behavior (1998).

147 More from RACHLINSKI in Sunstein (2000b).

148 Cf. on this effect of accountability in general TETLOCK in Journal of Personality and Social Psychology (1983a); LERNER and TETLOCK in Ramachandran (1994).

149 Bundesverfassungsgericht Feb. 20, 2001, R 54 (unpublished passage): "Zudem führt die Pflicht zur Dokumentation vor oder jedenfalls unmittelbar nach dem Eingriff dazu, dass sich der anordnende Beamte in besonderem Maße der Rechtmäßigkeit seines Handels vergewissert und dass er überdies im Falle der Nachprüfung dieses Handelns auf dokumentierte Tatsachen wird verweisen können, die sein Handeln erklären“; see also TETLOCK in Social Psychology Quarterly (1983b); TETLOCK and BOETTGER in Journal of Personality and Social Psychology (1989).

150 Cf. LERNER and TETLOCK in Psychological Bulletin (1999) 263. 
indirectly invite the parties to offer additional evidence. Also, the incentive to stop searching in the interest of saving face is still small.

Yet there is also a direct effect on the decision mode. The effect can have a cognitive and a motivational source. The cognitive path is via task construal. Interim representation makes the judge aware of the complexity of the task, ${ }^{151}$ and induces him to look for a decision mode that can accommodate this complexity. The cognitive effect can also be traced back to the friction that is generated by interim representation. ${ }^{152}$ The motivational path is via accountability. Interim representation makes accountability salient. Accountability has been demonstrated to have an effect on the choice of the decision mode. ${ }^{153}$ It induces subjects to invest more cognitive effort, ${ }^{154}$ and to become open to greater complexity of thought. ${ }^{155}$ Consequently, judges are likely to switch to deliberate reasoning, ${ }^{156}$ even if they were originally inclined to save cognitive effort by using heuristics, or to allow their emotions greater influence.

Above, it has been demonstrated that and why an absolute distinction between decision modes is inappropriate. A modularity approach is better. Interim representation is likely to have an impact on the choice of modules within deliberate reasoning. Hence, representation norms can use interim representation as a conduit. Via interim representation, judges become aware of the complexity of the case, and they are reminded of the interests and values that are at stake. It becomes more likely that intuition will be confined to the processes of starting a search, guiding a search and checking for the appropriateness of the outcome. This is precisely how the ideal of consciously controlled intuition is often characterised in law school education.

151 Cf. CVEtKovich in Social Psychology (1978); HAgAFORS and BreHMER in Organizational Behavior and Human Decision Processes (1983); WELDON and GARGANO in Personality and Social Psychology Bulletin (1988); cf. also PAYNE, BETTMAN and JOHNSON in Goldstein and Hogarth $(1997,184)$ on the effect of perceived uncertainty on the choice of the decision mode; PENNINGTON and HASTIE, in Goldstein and Hogarth $(1997,477)$, for the opposite shift in judicial decision mode.

152 Friction is not a standard category in psychological literature. But see AAKERMAN Friction (1993); ÅKERMAN The Necessity of Friction (1998) on this category in evolutionary thinking.

153 HAGAFORS and BREHMER in Organizational Behavior and Human Decision Processes (1983); see also PAYNE, BETTMAN and JOHNSON in Goldstein and Hogarth (1997) 182; LERNER and TETLOCK in Psychological Bulletin (1999) 259-262. Note, however, that some observers doubt whether "accountability [does] alter how people think, or merely what people say they think", LERNER and TETLOCK in Psychological Bulletin (1999) 266. Eventually this question turns out to be misleading. Impression management and cognition are closely intertwined, LERNER and TETLOCK in Psychological Bulletin (1999) 269.

154 MCAllister, Mitchell and BeACH in Organizational Behavior and Human Decision Processes (1979); WeLdON and GARgANO in Personality and Social Psychology Bulletin (1988); TETLOCK, SKITKA and BOETTGER in Journal of Personality and Social Psychology (1989) 633; ARKES in Psychological Bulletin (1991); ASHTON in Organizational Behavior and Human Decision Processes (1992).

155 TETLOCK and KIM in Journal of Personality and Social Psychology (1987); cf. also LERNER and TETLOCK in Psychological Bulletin (1999) 257: "when they were motivated to think and behave objectively, participants based their attitudes on evenhanded, systematic processing of the issued information".

156 MCAllister, Mitchell and BeACH in Organizational Behavior and Human Decision Processes (1979); CHAIKEN in Journal of Personality and Social Psychology (1980); HAGAFORS and BREHMER in Organizational Behavior and Human Decision Processes (1983); TETLOCK, SKITKA and BoETTGER in Journal of Personality and Social Psychology (1989) $638 \mathrm{f}$. 


\section{Simultaneous Representation}

Oral representation often entails (quasi-) simultaneous representation. The judge hears all the evidence and the pleadings of the parties, he decides the case, and he directly justifies his decision to the parties. In rather simple cases, this is the norm in German courtrooms.

Every academic has had the experience: teaching is the most effective way of learning. If one is obliged to explain an idea to uninitiated listeners, one becomes aware of what one only believed one had understood. Judges are in the same situation when they explain to the parties in the courtroom why the case had to be decided a particular way. In so doing, they are guided by representation norms. These norms thus impose an element of deliberation on judicial decision-making. For the reasons listed with respect to interim representation, this can have a beneficial effect on motivation, cognition and the choice of the decision mode.

Strictly speaking, however, oral representation is not an instance of simultaneous representation. According to prevailing norms, representation starts with a statement of what the judge has decided. Only afterwards are the reasons given. Even in this case, representation norms thus only affect judicial decision-making by anticipation. But due to the close proximity of both speech acts, such anticipation is highly likely. No judge would go back to the courtroom with nothing more substantial than his gut feelings. While making up his mind with respect to the final outcome, he must also prepare his explanation to the parties.

How does (quasi-) simultaneous representation compare to interim representation? When he takes his decision, the judge has already read the files and heard the evidence. Even in simple cases, the entire procedure lasts days, if not weeks. More complicated cases can keep a judge busy for months. The judge cannot but form a provisional opinion about how the case is likely to be decided in the end. This can have a hysteresis effect. All things being equal, one should therefore expect the countervailing power of representation to be weaker, the later it comes. There are, however, additional institutional safeguards. Before the judge takes his decision, the parties have an opportunity to plead, and to present the case in as favourable a light as they can. If the judge deems this appropriate, he can even reopen the procedure and hear new evidence. Also, in order to preserve the impression of impartiality, judges normally keep their provisional assessment of the case confidential. ${ }^{157}$ Consequently, there is typically no problem of saving face.

\section{Posterior Representation}

In judicial practice, oral and written representation can differ markedly. In oral representation, the judge above all speaks to the losing party. This party should understand why the case could not be decided otherwise. Consequently, in oral representation, judges tend to reduce the amount of legal jargon. Written representation has a much wider audience. It must meet full doctrinal standards. The higher the court, the more written representation also speaks to the legal community at large, 
if not to an even wider political community. This practice limits the countervailing effect of oral representation. If he has reached the decision rather intuitively, the judge can still meet with surprise when writing down the judgment. This is not a frequent event in judicial practice, but it happens. Specifically, it occurs in cases in which representation norms did not have a positive effect on the quality of the decision. Conversely, posterior representation can only improve the quality of a decision if it is anticipated at the moment of decision-making. There is indeed experimental evidence for this. ${ }^{158}$ But it does not distinguish between two possible mental paths.

One initial possibility is that the anticipation of representation will work as a check. In this scenario, the judge might reach his decision by any of the mental mechanisms. Before he enunciates it, he remembers that he will have to represent it in accordance with the prevailing representation norms. In preparing for representation, he becomes aware of information or arguments overlooked up till then. In line with this interpretation, the effect of representation norms is purely motivational. Judges anticipate the negative sanctions attached to substandard representation. If necessary, this makes them increase their cognitive effort.

This initial possibility will explain some, but not all instances. A second mental path is more likely. Representation norms have an impact on how judges construe their task. They do not split it up into two stages: one for reaching the decision, and a second one for meeting the requirements of representation norms. Rather, representation norms change how judges reach the decision in the first place. Another way of putting the difference between the two possibilities is the following: in the first case, the anticipation of representation is a last-minute activity. In the second case, representation is anticipated from the outset.

These mental mechanisms do not differ profoundly with respect to motivation. If the judge originally had been tempted to decide the case on illegitimate grounds, it suffices if a last-minute check prevents him from doing so. Due to the hermeneutical character of legal decision-making, however, judges have considerable leeway for justifying their decisions. Therefore, the legal order would prefer that representation norms change how the judicial task is construed.

This preference is even stronger from the perspective of debiasing. For a last-minute check has no direct cognitive effect. If representation norms have an impact on task construal, however, they influence how the judge goes about the judicial task from the very beginning. This makes it more likely that he will be faced with evidence or arguments that help debias him.

The preference is strongest if the legal order is directly interested in the judicial decision mode. A last-minute check is the quintessential instance of a judicial decision taken in a normatively suboptimal way. The legal order could be indifferent if this were an equally powerful technology for preventing suboptimal judicial output. But the section on judicial decision quality has demonstrated that this is not the case. Put differently, if the legal order is interested in the judicial deci-

158 Tetlock, SkitKa and BoetTGer in Journal of Personality and Social Psychology (1989) 633; see also STRACK and DEUTSCH Reflective and Impulsive (2002a) ***26 of pdf. 
sion mode at all, this interest must be driven by the conviction that the check should not be postponed until the last minute.

\section{Counter-Productive Effects?}

For lawyers, representation norms are evidently a good thing. From a psychological perspective, this is not so obvious. As has been repeatedly pointed out, representation norms hold judges accountable. Psychological research on accountability demonstrates that the effect of accountability on the decision quality is negative in many instances. There are three reasons for this: conformity (treated in a below); self-justification (treated in b); and loss of intuition (treated in c).

\section{a) Conformity}

Most people are "cognitive misers". ${ }^{159}$ They tend to exert as little effort as possible in solving their cognitive tasks. This explains why many subjects follow an "acceptability heuristic" when they are held accountable. ${ }^{160}$ They go for what they expect to be favoured by their audience. This strategy is, however, only available if they know their audience in advance. The effect disappears if the norms of the audience are not predictable. ${ }^{161}$ Judges know their audience. They have had an opportunity to observe the parties in trial. They are normally controlled by one and the same bench of the appellate court over a long period of time. In most domains, the volatility of the legal community is not pronounced. Nonetheless, a conformity effect is unlikely. For judges have a multifarious audience. It is not enough for the judge to convince the loser. The winner is also present in the courtroom. The written reasons can always be published by a reporter, and they may then well come under the critical eye of any trained lawyer.

\section{b) Self-Justification}

People do not want to appear foolish in front of their audiences. ${ }^{162}$ They care about the impression they make on others. ${ }^{163}$ Once they are committed to an outcome or a statement, evidence to the contrary exposes them to cognitive dissonance. ${ }^{164}$ Bringing their attitude in line with the outcome or statement is the easiest way to reduce this unpleasant mental situation. Both effects explain why accountability can generate "defensive bolstering", rather than an improvement in the decision quality. ${ }^{165}$ Posterior representation appears to bring judges into precisely this situation.

159 Tetlock, SkitKa and Boettger in Journal of Personality and Social Psychology (1989) 633.

160 Ibid.

161 Ibid.

162 SHAFIR, SimONSON and TVERSKY in Kahneman and Tversky (2000).

163 SCHLENKER Impression Management (1980).

164 On cognitive dissonance theory, see again FESTINGER Cognitive Dissonance (1957).

165 Tetlock, SkitKa and BoetTGer in Journal of Personality and Social Psychology (1989). 634; see also LERNER and TETLOCK in Psychological Bulletin (1999) 257. 
There are, however, mitigating effects. Defensive bolstering is less pronounced if the addressee of the justification has either less or more expertise than the decision-maker. If the addressee is less of an expert, the decision-maker can simply justify his decision on the basis his greater authority. If the addressee has more expertise, the decision-maker knows in advance that defensive bolstering will not help. ${ }^{166}$ Often, the parties will not be legal experts. Arguably, lower courts should attribute higher expertise to appellate courts.

Moreover, defensive bolstering is stronger if the decision-maker is held responsible for an outcome, rather than a process. ${ }^{167}$ The judicial task is somewhat ambivalent in this respect. Obviously, the outcome matters to the parties. But lawyers learn in the first term of their studies that the outcomes of cases are not fully predictable. There may be patently wrong decisions. But there is hardly ever just one obviously correct outcome. Consequently, both legal training and the institutional framework aim at safeguarding procedure much more than at safegaurding outcome. At closer sight, however, despite the same language, these legal considerations do not seem to match the psychological effect. Psychologically, the difference between outcome accountability and process accountability is seen as resulting from stress. ${ }^{168}$ The decision-maker feels he can keep the process under control. But if he is expected to take on responsibility for the outcome, regardless of how it came about, he feels victimised. In strict liability, the legal order generates precisely this situation. But judges have no reason to expect the outcomes of their own decisions to be the result of foreign forces. Put differently, they should always have the sense that accountability is confined to process, and does not extend to outcome.

\section{c) Loss of Intuition}

If incentives increase, people work harder on their choices, but they do not necessarily become smarter. ${ }^{169} \mathrm{~A}$ "motivation-difficulty model" explains the effect. ${ }^{170}$ Decision quality improves for standard tasks, but it deteriorates for unusual tasks. ${ }^{171}$ Subjects become more likely to exhibit dominant responses, ${ }^{172}$ and to respond to feedback. ${ }^{173}$ They focus on what they are good at. ${ }^{174}$ This comes at the expense of creative reactions, ${ }^{175}$ and in particular of intuitions. ${ }^{176}$ This thus shows an effect on the decision mode. Increased incentives block access to non-central strategies for deci-

166 FITZPATRICK and EAGLY in Personality and Social Psychology Bulletin (1981).

167 SimOnSON and STAW in Journal of Applied Psychology (1992); SIEGEL-JACOBS and YATES in Organizational Behavior and Human Decision Processes (1996).

168 JANIS and MANN Decision Making (1977); SIEGEL-JACOBS and YATES in Organizational Behavior and Human Decision Processes (1996) 2.

169 PAYNE, BETTMAN and JOHNSON in Goldstein and Hogarth (1997) 200.

170 PELHAM and NETER in Journal of Personality and Social Psychology (1995); LERNER and TETLOCK in Psychological Bulletin (1999) 259; the same effect has also been found with increased incentives for learning, Hogarth, GiBbS, MCKenZIE and MARQUIS in Goldstein and Hogarth (1997).

171 Pelham and NeTER in Journal of Personality and Social Psychology (1995) 582; see also HoGARTH, GIBBS, MCKENZIE and MARQUIS in Goldstein and Hogarth (1997) 247-249.

172 LERNER and TETLOCK in Psychological Bulletin (1999) 259.

173 SIEGEL-JACOBS and YATES in Organizational Behavior and Human Decision Processes (1996) 11.

174 Hogarth, GiBBS, MCKenZIE and MARQuis in Goldstein and Hogarth (1997) 247.

175 Ibid. in 249.

176 WILSON and SCHOOLER in Journal of Personality and Social Psychology (1991). 
sion-making. ${ }^{177}$ This is particularly disruptive for judgement tasks where multiple criteria ought to be taken into consideration. ${ }^{178}$ Most judicial tasks are precisely of this kind.

But the effect largely disappears in expert decision-making. ${ }^{179}$ This can best be explained by the fact that experienced decision-makers have access to many more specialised mental resources. What would be difficult for a lay person has become easy for them. ${ }^{180}$ Professional judges have a lot of experience in making legal decisions. The accountability effect resulting from representation norms should therefore not have a detrimental effect on the quality of their decisions. This should, however, be different in lay judges.

\section{Identity}

Under the influence of the law-and-economics movement, nowadays institutions are predominantly analysed with the help of fully decontextualised models. Consequently, the effect of institutions is assumed to be ad hoc. Sometimes, this is a helpful simplification. But at closer sight, the true effect of institutions, or at least its most powerful effect, occurs over a long-term timescale. Representation norms are no exception to this rule. As outlined in the previous sections, these norms can help keep judges on the normatively desired track. Should they occasionally feel tempted to deviate from this path, representation norms remind them of what is expected from them. But these rules can only have such an effect since they are embedded in a much richer framework of institutions. ${ }^{181}$ At the very least, this embeddedness makes these institutions much stronger.

The long-term effect of representation norms for judges rests on two grounds. Representation norms are part of a larger institutional arrangement for the creation of a professional identity. Moreover, representation norms assist individual judges in developing and improving their professional skills.

As outlined in the introduction, judges hold an office that society has entrusted to them. Society expects them to form an identity conscious of duty and deserving of respect. Society responds by expecting those who come to court to approach judges with due respect. There are many more tools for the purpose, like impressive court buildings, judges' robes and procedural formality. But the ritualistic character of representation is also part of this institutional arrangement. The expected effect has a reciprocating character. If he follows representation norms, the judge is reminded of his professional identity. But in so doing, his identity is also further corroborated.

Ibid. in 182; PELHAM and NETER in Journal of Personality and Social Psychology (1995) 582.

179 WILSON, KRAFT and DUNN in Journal of Experimental Social Psychology (1989); WILSON and SCHOOLER in Journal of Personality and Social Psychology (1991) 185; see also PELHAM and NETER in Journal of Personality and Social Psychology (1995) 592; LERNER and TETLOCK in Psychological Bulletin (1999) 263. 
As outlined earlier, the law wants the judge to take a decision that is stripped of personal intent. Representation norms contribute to reminding the judge that this is how society defines his role, and hence his professional identity. This is how representation norms can have a long-term effect on judicial motivation. The positive effects of identity on debiasing are more difficult to conceptualize. The pressure to fulfil a particular role has been shown to generate accountability. ${ }^{182}$ It could therefore add to the ad hoc effects of accountability outlined above. Likewise, the effect of professional identity on the choice of a decision mode should not be overstated. It would have to consist of something like a decision-making style that becomes characteristic for the profession. Judges would have to espouse a view something like "good judges do not make rash judgments".

While the positive effect of identity is likely to be profound, it should not be seen as a catch-all solution. For it has one important drawback. If the entire judiciary, or at least large parts of it, go astray, the tool is mute. Happily, however, this is fairly unlikely in most Western countries.

\section{Professional Skill}

Psychologically, anticipation is an imaginable, but demanding concept. At the very moment of decision-making, or at any relevant moment in the preparation of a decision, the subject must be aware of potential future consequences. He must pay attention to potential long-term effects. He must retrieve representation norms from memory. He must engage in weighing short-term and long-term effects. The more demanding the mental process, the less society may be certain that it will happen across the board. If representation norms are to improve decision quality, society should therefore prefer a less demanding mental mechanism.

There is indeed such a mechanism. There are several ways of characterising it. As a first approximation, it can be characterised as a broadened focus. Rather than looking at an individual instance of judicial decision-making in isolation, society is interested in moulding the stream of decisions taken by one judge. Technically, in this perspective, the impact of representation norms is not on current decisions, but on future ones. When taking the subsequent decisions, the judge recalls experiences he has had while representing earlier ones.

A second conceptualisation strays from the idea that the judge perceives representation norms as restrictions. He rather sees them as a way of defining the context. Specifically, from these norms, the judge may take the definition of the judicial output, of his task or of his role. Put differently, representation norms contribute to shaping the world as it is perceived by the judge. Psychologically, this works by the generation of schemata. ${ }^{183}$

The third and most powerful conceptualisation, however, is in terms of learning. In this perspective, representation norms are interpreted as prominent elements in an institutional arrangement. The purpose of this arrangement is to teach the judge how to generate. Such learning is not ad hoc,

182 ROZELLE and BAXTER in Journal of Applied Psychology (1981).

183 MANFRED SCHMITT pointed me to this. A classic on schemata is BARTLETT Remembering (1932). 
and it is not finished once a judge comes into office. Rather, learning is a protracted process: competence, ease and speed are improved. This interpretation thus entails three components: a learning object, a learning mechanism and an institutional arrangement.

The learning object is judicial skill. ${ }^{184}$ One aspect involves increasing the ease of decision-making. This occurs with routinisation. ${ }^{185}$ Part of the judicial task, such as assessing the credibility of witnesses, can eventually even become almost automatic. ${ }^{186}$ More important, however, is what has been dubbed progressive deepening. ${ }^{187}$ It has been investigated among chess masters. The following experiment shows its power. If lay people and trained chess players are asked to identify as many pieces as possible on a board of 25 unpatterned pieces, there is almost no difference in their results. ${ }^{188}$ The difference becomes dramatic, however, if the chessboard is patterned. Now, trained players recognise about 95\%; lay people some $25 \% .{ }^{189}$ Expertisation thus works by integrating individual pieces of information into larger and larger meaningful patterns. ${ }^{190}$ This also makes the result of learning more robust. Consequently, trained experts accept small errors but avoid large mistakes. $^{191}$

People possess a huge array of learning mechanisms. ${ }^{192}$ In principle, many of them could contribute to the development of judicial skill. There is some explicit instruction at university and even more such training when young lawyers assume jobs as judicial clerks. The judge may look up written sources, be they code, jurisprudence or hornbooks. A good deal of the individual skill of a judge will result from his experience in decision-making. It can thus be said to result from sequential trial and error. The most important learning mechanism, however, will normally be observation. ${ }^{193}$ During his training, every lawyer reads hundreds of cases. This exposes him to representation practice. Before the judge is allowed to sit alone, he usually has been a member of the judicial body for a while. Here he is able observe his more experienced peers. Observation is a powerful learning mechanism for two reasons. There is no need to gain all the experience individually. Moreover, observational learning does not just consist of imitation. Rather the observer builds an understanding of what the observed actors are doing. Such mental models have greater flexibility. Put differently, the context of observation and the context of application need not be identical.

Representation norms contribute to the development of judicial skills. But they are not the only form of institutional intervention useful for the purpose. Rather they should be seen as an important element in a richer institutional arrangement. ${ }^{194}$ Other elements include court organisation, ${ }^{195}$

184 Cf. KISCHEL Begründung (2003) 12.

185 More on this from ANDERSON Learning (2000) chapter 9.

186 The key text on automaticity is BARGH, CHEN and BURROWS in Journal of Personality and Social Psychology (1996).

187 KLEIN in Gigerenzer and Selten (2001) $114 \mathrm{f}$.

188 On average, lay people recognise 6 out of 25 pieces, trained players 7, SIMON Administrative Behavior. A Study of Decision-Making Processes in Administrative Organization (1976) 134.

189 Ibid. Administrative Behavior. A Study of Decision-Making Processes in Administrative Organization.

190 The classic study on this is GROOT Chess (1965)

191 GigERENZER, TODD and ABC RESEARCH GROUP Simple Heuristics (1999) 165.

192 For a comprehensive view, see ANDERSON Learning (2000).

193 The classic text on this is BANDURA Social Foundations (1986).

194 Cf. TRUTE in Schmidt-Aßmann and Hoffmann-Riem (2004) 311. 
including the interaction with higher courts; ${ }^{196}$ evidentiary rules that control the exposure to facts ${ }^{197}$ the organisation of court procedure, ${ }^{198}$ and its tournament character in particular; ${ }^{199}$ the frameworks for selecting and training judges; rules generating neutrality, like the judge's robe, or the rituals of interaction in the courtroom.

Does expertisation not only make judicial decision-making faster, but also better? The motivational effect is strongest if decision-making is indeed automatised. For then the decision-maker does not have recourse to any goal buffer or task construal mechanism before taking an individual decision. They are embedded in the description of the domain of the automatic decision rule. ${ }^{200}$ As mentioned earlier, this may be true for some elements in the judicial task. But due to the institutional framework, no judge will take a fully automatic final decision. Routinisation may, however, strongly narrow down the options taken into consideration. Thereby, the motivational defects listed above at least become less likely.

The debiasing power of expertisation is more pronounced. ${ }^{201}$ Anchoring provides a good illustration. It almost entirely resists training. But subjects can counteract the effect if they form subjective theories about contexts that bias their quantitative judgment. ${ }^{202}$ Along these lines, judges can progressively prepare to avoid falling prey to other biases as well. ${ }^{203}$

Most pronounced, however, is the effect of professionalisation on the choice of the decision mode. ${ }^{204}$ For expertisation means that judges do not only select normatively more appropriate decision modes. They even construct them for the purpose. The effect starts early on in legal training. Lawyers internalise the view that decisions must be based on reasons, but that they are not a mere logical exercise. They progressively learn how to handle the evidence and to give meaning to code with greater and greater elegance. They do not only learn to recognise larger chunks and patterns. More importantly even, they gain experience in discerning when a case does not fit into a pattern.

195 COHEN Inside Appellate Courts (2002); STEARNS in Michigan Law Review (2003).

196 Cf. KoRNHAUSER in Southern California Law Review (1995).

197 RACHLINSKI in Oregon Law Review (2000a) 71 f; GUTHRIE, RACHLINSKI and WistRICH in Cornell Law Review (2001) 823.

198 GUTHRIE, RACHLINSKI and WISTRICH in Cornell Law Review (2001) 828.

199 STALLARD and WORTHINGTON in Law and Human Behavior (1998); DRUCKMAN in Journal of Law, Economics and Organization (2001) 65 and 79.

200 More from ENGEL Social Dilemmas (2004b).

201 Cf. GoldSTEIN and HOGARTH in Goldstein and Hogarth (1997a) 29; JOLLS, SUNSTEIN and THALER in Stanford Law Review $(1998,1486)$ on the debiasing effect of professionalisation in general.

202 STRACK and DEUTSCH in Frey and Irle (2002b) 8.1.

203 The idea is as old as CARDOZO The Nature of the Judicial Process (1921) 176; see also GUTHRIE, RACHLINSKI and Wistrich, in Cornell Law Review (2001, 817, 826 and passim), on the power and the limitations of the approach.

204 Cf. GoldSTEIN and WeBER in Goldstein and Hogarth (1997) 598 f.: schema and category based decisionmaking presupposes expertise. 


\section{Conclusion}

As outlined in the introduction, the representation of judicial decisions is a multi-purpose activity. This paper has shown that one substantial effect is on decision quality. The effect can even be demonstrated on an ad hoc basis. Representation norms and the actual representation activity that is brought about by them have both a cognitive and a motivational effect. They palpably hold the judge accountable for the decision taken. And they guide him through the judgment elements inherent in his task. There is interplay between both effects when it comes to combating occasional non-normative motivation, debiasing and the choice of an appropriate decision mode. More importantly even than this short-term effect is the long-term power of representation norms. They exert this power as part and parcel of a richer institutional arrangement. That arrangement reminds the judge of the professional role he is playing, and it contributes to strengthening this attitude. And the institutional arrangement helps the judge in the process of progressive expertisation. Expertisation is no absolute protection against quality defects, but it is likely to significantly improve the quality of decisions. Suggestions for the deregulation of representation norms should pay due respect to the beneficial effect these norms have on the quality of decisions. 


\section{References}

AaKerman, Nordal (1993). The Necessity of Friction. Nineteen Essays on a Vital Force. Heidelberg, New York, Physica-Verlag, Springer-Verlag.

AdLER, MATTHEw D. (2000). "Expressive Theories of Law. A Skeptical Overview." University of Pennsylvania Law Review 148: 1363-1501.

AJZEN, ICEK and MARTin Fishbein (1980). Understanding Attitudes and Predicting Social Behavior. Englewood Cliffs, N.J., Prentice-Hall.

ÅKerman, Nordal (1998). The Necessity of Friction. Boulder, Colo., WestviewPress.

Albert, Hans (1978). Traktat über rationale Praxis. Tübingen, Mohr.

Anderson, Elizabeth and Richard H. Pildes (2000). "Expressive Theories of Law. A General Restatement." University of Pennsylvania Law Review 148: 1503-1575.

Anderson, JoHn R. (2000). Learning and Memory. An Integrated Approach. New York, Wiley.

ARKES, HAL R. (1991). "Costs and Benefits of Judgment Errors - Implications for Debiasing." Psychological Bulletin 110(3): 486-498.

Ashton, Robert H. (1992). "Effects of Justification and a Mechanical Aid on Judgment Performance." Organizational Behavior and Human Decision Processes 52: 292-306.

BABCOCK, LINDA and GEORGE LOEWENSTEIN (2000). Explaining Bargaining Impasse. The Role of Self-Serving Bias. Behavioral Law and Economics. Cass R. Sunstein. Cambridge, Cambridge University Press: 355-373.

BAlzer, Christian (1995). "Schlanke Entscheidungen im Zivilprozess." Neue Juristische Wochenschrift 48: 2448-2457.

Bandura, Albert (1986). Social Foundations of Thought and Action. A Social Cognitive Theory. Englewood Cliffs, N.J., Prentice-Hall.

Bargh, John A., Mark Chen, et al. (1996). "Automaticity of Social Behavior. Direct Effects of Trait Construct and Stereotype Activation on Action." Journal of Personality and Social Psychology 71: 230-244.

Bartlett, Frederic C. (1932). Remembering. A Study in Experimental and Social Psychology. Cambridge, [Eng.], The University Press.

BAumeIster, Roy (1982). "A Self-Presentational View of Social Phenomena." Psychological Bulletin 91: 3-26. 
Blais, AnN-ReneE and Elke U. Weber (2001). "Domain-Specificity and Gender Differences in Decision Making." Risk Decision and Policy 6: 47-69.

BoHner, GERD (2001). Attitudes. Introduction to Social Psychology. Miles Hewstone and Wolfgang Stroebe. Oxford, Blackwell: 239-282.

Bohnet, Iris and Robert D. CoOTER (2001). Expressive Law. Framing or Equilibrium Selection? http://ksghome.harvard.edu/ .ibohnet.academic.ksg/Bohnet_Cooter.doc.

BRECHER, FRITZ (1958). Scheinbegründungen und Methodenehrlichkeit im Zivilrecht. Festschrift Arthur Nikisch. Tübingen, Mohr: 227-247.

Brehm, JaCK Williams (1966). A Theory of Psychological Reactance. New York, Academic Press.

Brehm, Sharon S. and Jack Williams Brehm (1981). Psychological Reactance. A Theory of Freedom and Control. New York, Academic Press.

Brennan, Geoffrey and Philip Pettit (2000). "The Hidden Economy of Esteem." Economics and Philosophy 16: 77-98.

Brennan, Geoffrey and Philip Pettit (2004). The Economy of Esteem. An Essay on Civil and Political Society. Oxford; New York, Oxford University Press.

BRINK, SteFAN (1999). Über die richterliche Entscheidungsbegründung. Funktion - Position Methodik. Frankfurt, Lang.

Bruner, Jerome S. (1986). Actual Minds, Possible Worlds. Cambridge, Mass., Harvard University Press.

Bruner, Jerome S. (1990). Acts of Meaning. Cambridge, Mass., Harvard University Press.

BRUnSSON, NiLS (1989). The organization of Hypocrisy. Talk, Decisions, and Actions in Arganizations. Chichester; New York, Wiley.

Busemeyer, J.R. and J.T. Townsend (1993). "Decision Field Theory. A Dynamic Cognitive Approach to Decision Making in an Uncertain Environment." Psychological Review 100: 432-459.

CAmerer, Colin F. (1995). Individual Decision Making. Handbook of Experimental Economics. John H. Kagel and Alvin E. Roth. Princeton, Princeton University Press: 587-703.

Cardozo, Benjamin N. (1921). The Nature of the Judicial Process. New Haven, Yale University Press. 
Chaiken, Shelly (1980). "Heuristic Versus Systematic Information Processing and the Use of Source Versus Message Cues in Persuasion." Journal of Personality and Social Psychology 39: $752-766$.

Chaiken, Shelly and YaAcov Trope (1999). Dual-process Theories in Social Psychology. New York, Guilford Press.

Cohen, Jonathan MatTHew (2002). Inside Appellate Courts. The Impact of Court Organization on Judicial Decision Making in the United States Courts of Appeals. Ann Arbor, University of Michigan Press.

ConLisk, JoHn (1996). "Why Bounded Rationality?" Journal of Economic Literature 34: 669-700.

COOTER, Robert (1998). "Expressive Law and Economics." Journal of Legal Studies 27: 585608.

Cvetkovich, George (1978). "Cognitive Accommodation, Language, and Social Responsibility." Social Psychology 41: 149-155.

DASTON, LORRAINE (1999). Objectivity versus Truth. Wissenschaft als kulturelle Praxis, 17501900. Hans Erich Bödeker, Peter Hanns Reill and Jürgen Schlumbohm. Göttingen, Vandenhoeck \& Rupprecht: 17-32.

DAVIES, MARTIN F. (1987). "Reduction of Hindsight Bias by Restoration of Foresight Perspective. Effectiveness of Foresight-Encoding and Hindsight-Retrieval." Organizational Behavior and Human Decision Processes 40: 50-68.

Donnell, A. J., A. Thomas, et al. (2001). "Psychological Reactance. Factor Structure and Internal Consistency of the Questionnaire for the Measurement of Psychological Reactance." Journal of Social Psychology 141(5): 679-687.

Druckman, JAmes (2001). "Using Credible Advice to Overcome Framing Effects." Journal of Law, Economics and Organization 17: 62-82.

Engel, Christoph (2001a). Die Grammatik des Rechts. Instrumente des Umweltschutzes im Wirkungsverbund. Hans-Werner Rengeling. Baden-Baden, Nomos: 17-49.

Engel, Christoph (2001b). "Offene Gemeinwohldefinitionen." Rechtstheorie 32: 23-52.

Engel, Christoph (2004a). Learning the Law. Preprints of the Max Planck Institute for Research on Collective Goods Bonn 2004/5.

Engel, Christoph (2004b). Social Dilemmas, Revisited from a Heuristics Perspective. Preprints of the Max Planck Institute for Research on Collective Goods Bonn 2004/4. 
Englich, BiRte and Thomas Mussweiler (2001). "Sentencing under Uncertainty. Anchoring Effects in the Court Room." Journal of Applied Social Psychology 31: 1535-1551.

Evans, Jonathan St.B.T. and David E. Over (1997). "Are People Rational? Yes, No, and Sometimes." Psychologist: 403-406.

FARnsworth, WARD (2000). Do Parties to Nuisance Cases Bargain After Judgement ? A Glimpse into the Cathedral. Behavioral Law and Economics. Cass R. Sunstein. Cambridge, Cambridge University Press: 302-322.

FARnSWORTH, WARD (2003). "The Legal Management of Self-Serving Bias." University of California at Davis Law Review 37: 567-603.

FESTINGER, LEON (1957). A Theory of Cognitive Dissonance. Evanston, Ill., Row Peterson.

FIEDler, Klaus (2000). "Beware of Samples! A Cognitive-Ecological Sampling Approach to Judgement Bias." Psychological Review 107: 659-676.

FISCHHOFF, BARUCH (1975). "Hindsight Is Not Equal to Foresight. The Effect of Outcome Knowledge on Judgment under Uncertainty." Journal of Experimental Psychology: Human Perception \& Performance 1: 288-299.

FISCHHOFF, BARUCH (1977). "Perceived Informativeness of Facts." Journal of Experimental Psychology 3: 349-358.

FitzPatrick, Anne R. and Alice H. Eagly (1981). "Anticipatory Belief Polarization as a Function of the Expertise of a Discussion Partner." Personality and Social Psychology Bulletin 7: 636-642.

Frank, Jerome (1949). Courts on Trial. Myth and Reality in American Justice. Princeton, Princeton University Press.

FREY, BRUNO and IRIS BOHNET (1995). "Institutions affect Fairness." Journal of Institutional and Theoretical Economics 151: 286-303.

FREY, BRUNO and REINER EICHENBERGER (1994). "Economic Incentives Transform Psychological Anomalies." Journal of Economic Behavior and Organization 23: 215-234.

Frey, Bruno and Alois Stutzer (2001). Beyond Bentham - Measuring Procedural Utility. CESifo Working Papers 492. http://papers.ssrn.com/abstract=268059.

Gigerenzer, Gerd, Peter M. TodD, et al. (1999). Simple Heuristics that Make us Smart. New York, Oxford University Press. 
Goldstein, William M. and Robin M. Hogarth (1997a). Judgment and Decision Research. Some Historical Context. Research on Judgement and Decision Making. William M. Goldstein and Robin M. Hogarth. Cambridge, Cambridge University Press: 3-65.

Goldstein, William M. and Robin M. Hogarth (1997b). Research on Judgment and Decision Making. Currents, Connections, and Controversies. Cambridge, Cambridgeshire; New York, Cambridge University Press.

Goldstein, William M. and Elke U. Weber (1997). Content and Discontent. Indications and Implications of Domain Specificity in Preferential Decision Making. Research in Judgement and Decision Making. William M. Goldstein and Robin M. Hogarth. Cambridge, Cambridge University Press: 566-617.

Granovetter, Marc (1985). "Economic Action and Social Structure. The Problem of Embeddedness." American Journal of Sociology 91: 481-510.

Groot, Adrianus Dingeman DE (1965). Thought and Choice in Chess. The Hague, Mouton.

Guthrie, Chris, JefFrey J. RaChlinski, et al. (2001). "Inside the Judicial Mind." Cornell Law Review 86: 777-830.

Hagafors, Roger and Berndt Brehmer (1983). "Does Having to Justify one's Judgments Change the Nature of the Judgment Process?" Organizational Behavior and Human Decision Processes 31: 223-232.

Hastie, ReID (1993). Inside the Juror. The Psychology of Juror Decision Making. Cambridge England; New York, NY, Cambridge University Press.

Hastie, Reid, Steven Penrod, et al. (1983). Inside the Jury. Cambridge, Mass., Harvard University Press.

Hastie, ReID, David SchKade, et al. (1999). "Juror Judgments in Civil Cases: Hindsight Effects on Judgments of Liability for Punitive Damages." Law and Human Behavior. 23: 597-614.

Hawkins, Scott A. and Reed Hastie (1990). "Hindsight: Biased Judgments of Past Events after the Outcomes Are Known." Psychological Bulletin 107: 311-327.

Heitmann, StefFen (1997). "Plädoyer für ein Auslaufmodell." Neue Juristische Wochenschrift 50: $1826-1827$.

HÉRITIER, AdrIENNE (1999). Policy-making and Diversity in Europe. Escaping Deadlock. Cambridge, UK; New York, Cambridge University Press.

Hinsz, Verlin B. and Kristin E. InDAhl (1995). "Assimilation to Anchors for Damage Awards in a Mock Civil Trial." Journal of Applied Social Psychology 25: 991-1026. 
Hogarth, Robin M., Brian J. GiBbS, et al. (1997). Learning from Feedback. Exactingness and Incentives. Research on Judgement and Decision Making. William M. Goldstein and Robin M. Hogarth. Cambridge, Cambridge University Press: 244-284.

Hull, Clark LeOnard (1943). Principles of Behavior. An Introduction to Behavior Theory. New York, Appleton.

JAKOBS, GÜNTHER (1999). Norm, Person, Gesellschaft. Vorüberlegungen zu einer Rechtsphilosophie. Berlin, Duncker \& Humblot.

JAnis, IRving Lester and LeOn MAnN (1977). Decision Making. A Psychological Analysis of Conflict, Choice, and Commitment. New York, Free Press.

Jolls, Christine, CAss R. Sunstein, et al. (1998). "A Behavioral Approach to Law and Economics." Stanford Law Review 50: 1471-1550.

Kahneman, Daniel, Jack L. Knetsch, et al. (2000). Anomalies: The Endowment Effect, Loss Aversion and Status Quo Bias. Choices, Values, and Frames. Daniel Kahneman and Amos Tversky. Cambridge, Cambridge University Press: 159-170.

Kahneman, Daniel and Amos TVersky (1972). "Subjective Probability. A Judgement of Representativeness." Cognitive Psychology 3: 430-454.

Kahneman, Daniel and Amos TVersky (2000). Choices, Values, and Frames. Choices, Values, and Frames. Daniel Kahneman and Amos Tversky. Cambridge, Cambridge University Press: $1-16$.

Kashima, Yoshinisa, Allison McKintyre, et al. (1998). "The Category of the Mind. Folk Psychology of Belief, Desire, and Intention." Asian Journal of Social Psychology 1: 289313.

Kelman, Mark (1987). A Guide to Critical Legal Studies. Cambridge, Mass., Harvard University Press.

Kelman, Mark, Yuval Rottenstreich, et al. (2000). Context-Dependence in Legal Decision Making. Behavioural Law and Economics. Cass R. Sunstein. Cambridge, Cambridge University Press: 61-94.

Kerr, Norbert L., Robert J. MacCoun, et al. (1996). "Bias in Judgment. Comparing Individuals and Groups." Psychological Review 103: 687-719.

Kischel, UwE (2003). Die Begründung. Zur Erläuterung staatlicher Entscheidungen gegenüber dem Bürger. Tübingen, Mohr. 
Kitchener, Karen Strohm (2002a). "Skills, Tasks, and Definitions. Discrepancies in the Understanding and Data on the Development of Folk Epistemology." New Ideas in Psychology 20: 309-328.

KitCHENER, RichaRD F. (2002b). "Folk Epistemology. An Introduction." New Ideas in Psychology 20: 89-105.

KleIn, Gary (2001). The Fiction of Optimization. Bounded Rationality. The Adaptive Toolbox. Dahlem Workshop Report. Gerd Gigerenzer and Reinhard Selten. Cambridge, MA, MIT Press: $103-121$.

KoEHLER, JonAthan (1990). "Veridical Verdicts. Increasing Verdict Accuracy Through the Use of Overtly Probabilistic Evidence and Methods." Cornell Law Review 75: 247-279.

Koehler, Jonathan (2005). Train our Jurors. Heuristics and the Law. Christoph Engel and Gerd Gigerenzer. Cambridge, MIT Press: ***.

Kornhauser, LewiS A. (1992). "Modelling Collegial Courts I: Path-Dependence." International Review of Law and Economics 12: 169-185.

KoRnhauser, Lewis A. (1995). "Adjudication by a Resource-Constrained Team. Hierarchy and Precedent in a Judicial System." Southern California Law Review 68: 1605-1629.

Kornhauser, Lewis A. and Lawrence G. Sage (1993). "The One and the Many. Adjudication in Collegial Courts." California Law Review 81: 1-59.

Kruglanski, Arie W. and Tallie Freund (1983). "The Freezing and Unfreezing of LayInferences. Effects on Impressional Primacy, Ethnic Stereotyping, and Numerical Anchoring." Journal of Experimental Social Psychology 19: 448-468.

LaBine, Susan and Gary LaBine (1996). "Determinations of Negligence and the Hindsight Bias." Law and Human Behavior. 20: 501-516.

Lerner, Jennifer S., Julie H. Goldberg, et al. (1998). "Sober Second Thought. The Effects of Accountability, Anger, and Authoritarianism on Attributions of Responsibility." Personality and Social Psychology Bulletin 24: 563-574.

Lerner, Jennifer S. and Philip E. Tetlock (1994). Accountability and Social Cognition. Encyclopedia of Human Behavior. Vilayanur Ramachandran. San Diego, Academic Press. 1: 3098-3121.

LERner, Jennifer S. and PhiLIP E. TeTlock (1999). "Accounting for the Effects of Accountability." Psychological Bulletin 125: 255-275.

Levinson, StePhen C. (1995). Interactional Biases in Human Thinking. Social Intelligence and Interaction. Esther Goody. Cambridge, Cambridge University Press: 221-260. 
LEWIS, MARC D. (2004). "Bridging Emotion Theory and Neurobiology Through Dynamic Systems." Behavioral and Brain Sciences $* * *$ : ***.

LUHMANN, NiKLAS (1966). Recht und Automation in der öffentlichen Verwaltung. Eine verwaltungswissenschaftliche Untersuchung. Berlin, Duncker \& Humblot.

Lupfer, Michael B., Kelly P. Weeks, et al. (2000). "Folk Conceptions of Fairness and Unfairness." European Journal of Social Psychology 30: 405-428.

Macey, Jonathan R. (1994). "Judicial Preferences, Public Choice, and the Rules of Procedure." Journal of Legal Studies 23: 627-646.

Malle, Bertram F. (1997). "The Folk Concept of Intentionality." Journal of Experimental Social Psychology 33: 101-121.

MantZavinos, Chrysostomos (2004). Hermeneutische Irrwege und Auswege, ***.

MAUReR, HARTMUt (2002). Allgemeines Verwaltungsrecht. München, Beck.

MCAdAms, Richard H. (2000). "A Focal Point Theory of Expressive Law." Virginia Law Review 86: 1649-1729.

McAllister, Daniel W., Terence R. Mitchell, et al. (1979). "The Contingency Model for the Selection of Decision Strategies. An Empirical Test of the Effects of Significance, Accountability, and Reversibility." Organizational Behavior and Human Decision Processes 24: 228244.

McCaffery, Edward, Daniel Kahneman, et al. (2000). Framing the Jury. Cognitive Perspective on Pain and Suffering Awards. Behavioral Law and Economics. Cass R. Sunstein. Cambridge, Cambridge University Press: 259-287.

McCormaC, John W. (1994). "Reason Comes Before Decision." Ohio State Law Journal 55: 161166.

Montesquieu, Charles louis de Secondat (1748). De l'esprit des loix. n. p.

MorloK, Martin and Ralf Kölbel (2000). "Zur Herstellung von Recht. Forschungsstand und rechtstheoretische Implikationen ethnomethodologischer (Straf-)Rechtssoziologie." Zeitschrift für Rechtssoziologie 21: 387-417.

Neumann, UlfRID (2001). "Juristische Methodenlehre und Theorie der juristischen Argumentation." Rechtstheorie 32: 239-255.

Nisbett, Richard E., Craig Caputo, et al. (1976). "Behavior as Seen by the Actor and as Seen by the Observer." Journal of Personality and Social Psychology 27: 154-164. 
NisbetT, Richard E. and LeE Ross (1980). Human Inference. Strategies and Shortcomings of Social Judgment. Englewood Cliffs, N.J., Prentice-Hall.

Noll, Roger and JAmes E. Krier (2000). Some Implications of Cognitive Psychology for Risk Regulation. Behavioral Law and Economics. Cass R. Sunstein. Cambridge, Cambridge University Press: 325-354.

OEHLERS, Horst (1994). "Von dem, was der Revisionsrichter zu lesen und der Tatrichter zu schreiben hat." Neue Juristische Wochenschrift 47: 712-713.

Payne, John W., James R. Bettman, et al. (1988). "Adaptive Strategy Selection in Decision Making." Journal of Experimental Psychology 14: 534-552.

Payne, John W., James R. Bettman, et al. (1997). The Adaptive Decision Maker. Effort and Accuracy in Choice. Research on Judgement and Decision Making. Currents, Connections, and Controversies. William M. Goldstein and Robin M. Hogarth. Cambridge, Cambridge University Press: 181-204.

Pelham, Brett and Efrat Neter (1995). "The Effect of Motivation of Judgment Depends on the Difficulty of the Judgment." Journal of Personality and Social Psychology 68: 581-594.

Pennington, Nancy and Reed Hastie (1993). The Story Model for Juror Decision Making. Inside the Juror. The Psychology of Juror Decision Making. Reed Hastie. Cambridge, Cambridge University Press: 192-221.

Pennington, Nancy and Reid Hastie (1997). Explanation-Based Decision Making. Effects of Memory Structure on Judgement. Research in Judgement and Decision Making. William M. Goldstein and Robin M. Hogarth. Cambridge, Cambridge University Press: 454-481.

POPPER, KARL RAIMUND (1935). Logik der Forschung. Zur Erkenntnistheorie der modernen Naturwissenschaft. Wien, J. Springer.

Posner, Richard A. (1993). "What Do Judges and Justices Maximize? (The Same Thing Everybody Else Does)." Supreme Court Economic Review 3: 1-41.

Quinn, John R. (1996). "'Attitudinal" Decision Making in the Federal Courts. A Study of Constitutional Self-Representation Claims." San Diego Law Review 33: 701-754.

RACHLINSKI, JeFFREY J. (2000a). "Heuristics and Biases in the Courts. Ignorance or Adaptation?" Oregon Law Review 79: 61-102.

Rachlinski, Jefrrey J. (2000b). A Positive Psychological Theory of Judging in Hindsight. Behavioral Law and Economics. Cass R. Sunstein. Cambridge, Cambridge University Press: 95-115. 
RACHLINSKI, JEFFREY J. (2005). Bottom-up versus Top-down Lawmaking. Heuristics and the Law. Christoph Engel and Gerd Gigerenzer. Cambridge, MA, MIT Press: ***.

RAFI, ANUSHEH (2004). Kriterien für ein gutes Urteil. Berlin, Duncker \& Humblot.

Ross, LeE D. (1976). The Intuitive Psychologist and his Shortcomings. Distortions in the Attribution Process. Advances in Experimental Social Psychology. Leonard Berkowitz. New York, Academic Press: 174-221.

Rozelle, Richard M. and James C. BAXter (1981). "Influence of Role Pressures on the Perceiver. Judgments of Videotaped Interviews Varying Judge Accountability and Responsibility." Journal of Applied Psychology 66: 437-441.

Rubin, Edward L. (1996). "The New Legal Process, the Synthesis of Discourse, and the Microanalysis of Institutions." Harvard Law Review 109: 1393-1438.

SCHARPF, Fritz Wilhelm (1997). Games Real Actors Play. Actor-Centered Institutionalism in Policy Research. Boulder, Colo., Westview Press.

SCHAUER, FREDERICK (1995). "Giving Reasons." Stanford Law Review 47: 633-659.

SCHLENKER, BARRY R. (1980). Impression Management. The Self-Concept, Social Identity and Interpersonal Relations. Monterey, Brooks.

Schlicht, EKKEHART (1998). On Custom in the Economy. Oxford, Clarendon Press.

SCHLINK, BERnHARD (1980). "Bemerkungen zum Stand der Methodendiskussion in der Verfassungsrechtswissenschaft." Staat 19: 73-107.

SCHMitT, MANFRED (1996). "Individual Differences in Sensitivity to Befallen Injustice." Personality and Individual Differences 21: 3-20.

Schulz, JoAchim (1992). Sachverhaltsfeststellung und Beweistheorie. Elemente einer Theorie strafprozessualer Sachverhaltsfeststellung. Köln, Heymanns.

Schumann, Claus-Dieter (1993). "Zur Beweiskraft des Tatbestands im Rechtsmittelverfahren." Neue Juristische Wochenschrift 46: 2786-2788.

SCHUPPERT, GUNNAR FOLKE (2003). Staatswissenschaft. Baden-Baden, Nomos.

SchuschKe, Winfried and Hermann Daubenspeck (2003). Bericht, Gutachten und Urteil. München, Vahlen.

Segal, Jeffrey Allan and Harold J. Spaeth (1993). The Supreme Court and the Attitudinal Model. Cambridge; New York, NY, Cambridge University Press. 
Segal, Jeffrey Allan and Harold J. Spaeth (2002). The Supreme Court and the Attitudinal Model Revisited. Cambridge, UK; New York, Cambridge University Press.

Shafir, Eldar, ItAmar Simonson, et al. (2000). Reason-Based Choice. Choices, Values, and Frames. Daniel Kahneman and Amos Tversky. Cambridge, Cambridge University Press: 597-619.

Siegel-Jacobs, Karen and J. Frank YATES (1996). "Effects of Procedural and Outcome Accountability on Judgment Quality." Organizational Behavior and Human Decision Processes 65: 1-17.

SIMON, DiETER (1975). Die Unabhängigkeit des Richters. Darmstadt, Wissenschaftliche Buchgesellschaft.

Simon, Herbert AleXANDER (1976). Administrative Behavior. A Study of Decision-Making Processes in Administrative Organization. New York, Free Press.

Simonson, Itamar and Peter Nye (1992). "The Effect of Accountability on Susceptibility to Decision Errors." Organizational Behavior and Human Decision Processes 51: 416-446.

SimONSON, ItAMAR and BARRY M. StAW (1992). "Deescalation Strategies. A Comparison of Techniques for Reducing Commitment to Losing Courses of Action." Journal of Applied Psychology 77: 419-426.

SMITH, AdAm (1790). The Theory of Moral Sentiments, or, An Essay Towards an Analysis of the Principles by which Men Naturally Judge Concerning the Conduct and Character, First of Their Neighbours, and Afterwards of Themselves. To which is Added, a Dissertation on the Origin of Languages. London, Strahan.

SPence, Kenneth Wartenbee (1956). Behavior Theory and Conditioning. New Haven, Yale University Press.

Stallard, Merrie Jo and Debra L. Worthington (1998). "Reducing the Hindsight Bias Utilizing Attorney Closing Arguments." Law and Human Behavior 22: 671-683.

StANOVICH, Keith E. and Richard F. West (2000). "Individual Differences in Reasoning. Implications for the Rationality Debate?" Behavioral and Brain Sciences 23: 645-665.

Stearns, MaXwell L. (2003). "Appellate Courts In and Out." Michigan Law Review 101: 17641790.

Steiner, Benjamin D., William J. Bowers, et al. (1999). "Folk Knowledge as Legal Action. Death Penalty Judgements and the Tenet of Early Release in a Culture of Mistrust and Punitiveness." Law and Society Review 33: 461-505. 
StRACK, Fritz and Roland DeUTSCh (2002a). Reflective and Impulsive Determinants of Social Behaviour.

STRACK, FRITZ and Roland DEUTSCH (2002b). Urteilsheuristiken. Theorien der Sozialpsychologie - Motivations- und Informationsverarbeitungstheorien. Dieter Frey and Martin Irle: 352384.

Strack, Fritz and Thomas Mussweiler (1997). "Explaining the Enigmatic Anchoring Effect. Mechanisms of Selective Accessibility." Journal of Personality and Social Psychology 73: 437-446.

Sunstein, CASS R. (1995). "Incompletely Theorized Agreements." 1733-1772.

Svenson, Ola (1981). "Are We All Less Risky and More Skilful Than Our Fellow Drivers?" Acta Psychologica 47: 143-148.

Tetlock, PhiliP E. (1983a). "Accountability and Complexity of Thought." Journal of Personality and Social Psychology 45: 74-83.

Tetlock, PhiliP E. (1983b). "Accountability and the Perseverance of First Impressions." Social Psychology Quarterly 46: 285-292.

Tetlock, Philip E. (1985a). "Accountability. A Social Check on the Fundamental Attribution Error." Social Psychology Quarterly 48: 227-236.

Tetlock, Philip E. (1985b). "Accountability. The Neglected Social Context of Judgement and Choice." Research in Organizational Behaviour 7: 297-332.

Tetlock, PhiliP E. (1999). Accountability Theory. Mixing Properties of Human Agents with Properties of Social Systems. Shared Cognition in Organizations. The Management of Knowledge. Leigh L. Thompson, John M. Levine and David M. Messick. Mahwah, Erlbaum: 117-137.

Tetlock, Philip E. and Richard Boettger (1989). "Accountability. A Social Magnifier of the Dilution Effect." Journal of Personality and Social Psychology 57: 388-398.

Tetlock, PhiliP E. and JAe II Kim (1987). "Accountability and Judgment Processes in a Personality Prediction Task." Journal of Personality and Social Psychology 52: 700-709.

Tetlock, PhiliP E., Linda SkitKA, et al. (1989). "Social and Cognitive Strategies for Coping with Accountability. Conformity, Complexity, and Bolstering." Journal of Personality and Social Psychology 57: 632-640.

Thomas, R. Murray (2001). Folk Psychologies Across Cultures. Thousand Oaks, Calif., Sage Publications. 
TRUTE, HANS HeINRICH (2004). Methodik der Herstellung und Darstellung verwaltungsrechtlicher Entscheidungen. Methoden der Verwaltungsrechtswissenschaft. Eberhard Schmidt-Aßmann and Wolfgang Hoffmann-Riem. Baden-Baden, Nomos: 293-325.

TuRner, MARK (2001). Cognitive Dimensions of Social Science. New York, Oxford University Press.

TVERSKY, Amos and DANIEL KAHNEMAN (1974). "Judgement under Uncertainty: Heuristics and Biases." Science 185: 1124-1131.

TVersky, Amos and Daniel Kahneman (1981). "The Framing of Decisions and the Psychology of Choice." Science 211: 453-458.

TVERsky, Amos and DANiEl Kahneman (1982). Judgement of and by Representativeness. Judgement Under Uncertainty. Heuristics and Biases. Daniel Kahneman, Paul Slovic and Amos Tversky. Cambridge, Cambridge University Press: 84-100.

Tyler, Tom R. (1990). Why People Obey the Law. New Haven, Yale University Press.

VON Winterfeldt, Detlof and WARd EdWARds (1986). "Cognitive Illusions and their Implications for the Law." Southern California Law Review 59: 225-276.

Wegener, Duane T. and Richard E. Petty (1995). "Flexible Correction Processes in Social Judgment. The Role of Naive Theories in Corrections for Perceived Bias." Journal of Personality and Social Psychology 68: 36-51.

Weldon, Elizabeth and Gina M. Gargano (1988). "Cognitive Loafing. The Effects of Accountability and Shared Responsibility on Cognitive Effort." Personality and Social Psychology Bulletin 14: 159-171.

WILSON, T.D. and J.W. SchOOLER (1991). "Thinking too Much. Introspection can Reduce the Quality of Preferences and decisions." Journal of Personality and Social Psychology 60: 181-192.

Wilson, Timothy D., Dolores Kraft, et al. (1989). "The Disruptive Effects of Explaining Attitudes. The Moderating Effect of Knowledge about the Attitude Object." Journal of Experimental Social Psychology 25: 379-400.

ZAJONC, RoBert B. (1965). "Social Facilitation." Science 149: 269-274.

ZIMAN, J. M. (2000). Real Science. What it Is, and What it Means. Cambridge; New York, Cambridge University Press.

Zimmermann, Walter and HANS Berg (2003). Klage, Gutachten und Urteil. Heidelberg, C.F.Müller. 


\section{Max Planck Institute for Research on Collective Goods}

\section{Preprints 2004}

95. Hendrik Hakenes / Isabel Schnabel, Banks without Parachutes - Competitive Effects of Government Bail-out Policies. $2004 / 12$.

94. Markus Englerth, Behavioral Law and Economics - eine kritische Einführung. 2004/11.

93. C. Christian von Weizsäcker, Marktzutrittsschranken. 2004/10.

92. Martin Beckenkamp, Institutionelle Ergonomie. Verhaltensrelevante Variablen zur Beeinflussung kooperativen Verhaltens in sozialen Dilemmata. 2004/9.

91. Martin F. Hellwig, Nonlinear Incentive Provision in Walrasian Markets: A Cournot Convergence Approach. 2004/8.

90. Dirk De Bièvre, Governance in International Trade: Judicialisation and Positive Integration in the WTO. 2004/7.

89. Martin F. Hellwig, Risk Aversion in the Small and in the Large. When Outcomes are Multidimensional. 2004/6.

88. Christoph Engel, Learning the Law. 2004/5.

87. Christoph Engel, Social Dilemmas, Revisited from a Heuristics Perspective. 2004/4. forthcoming in: Christoph Engel / Gerd Gigerenzer (eds.): Heuristics and the Law. Dahlem Conference. MIT Press

86. Alkuin Kölliker: Globalisation and National Incentives for Protecting Environmental Goods. 2004/3.

85. Frank P. Maier-Rigaud / Jose Apesteguia: The Role of Rivalry. Public Goods versus Common-Pool Resources. 2004/2.

84a. C. Mantzavinos: The Institutional-Evolutionary Antitrust Model. 2004/1(a).

84. C. Mantzavinos: Das institutionenökonomisch-evolutionäre Wettbewerbsleitbild. 2004/1.

\section{Preprints 2003}

83. C. Mantzavinos, Douglass C. North, Syed Shariq: Learning, Institutions and Economic Performance. 2003/13. forthcoming in: Perspectives on Politics, vol. 2, March 2004.

82. Stefan Magen: Staatskirchenrecht als symbolisches Recht? 2003/12.

81. Christoph Engel: Marktabgrenzung als soziale Konstruktion. 2003/11.

published in: Andreas Fuchs / Hans-Peter Schwintowski / Daniel Zimmer (Hrsg.): Festschrift für Ulrich Immenga zum 70. Geburtstag, München 2004, 127-147.

80. Christoph Engel: Governing the Egalitarians from Without. The Case of the Internet. 2003/10.

79. Christoph Engel: Freiheit und Autonomie. 2003/9.

forthcoming in:

Detlef Merten / Hans-Jürgen Papier (eds.) Handbuch der Grundrechte II 
78. Pieter Bouwen: The Democratic Legitimacy of Business Interest Representation in the European Union: Normative Implications of the Logic of Access. 2003/8.

77. Frank P. Maier-Rigaud / Jose Apesteguia: The Role of Choice in Social Dilemma Experiments. 2003/7.

76. Florian Becker / Dirk Lehmkuhl: Multiple Strukturen der Regulierung: Ursachen, Konflikte und Lösungen am Fall des Leichtathleten Baumann. 2003/6.

75. Indra Spiecker gen. Döhmann: US-amerikanisches Chemikalienrecht im Vergleich - Informationsgewinnung und Entscheidung unter Unsicherheit. 2003/5.

published as:

US-amerikanisches Chemikalienrecht im Vergleich - Informationsgewinnung und Entscheidung unter Unsicherheit, in Rengeling, Hans-Werner (Hrsg.), Umgestaltung des deutschen Chemikalienrechts durch europäische Chemikalienpolitik, Köln 2003, S.151 ff.

74. Bas Arts, University of Nijmegen: Non-State Actors in Global Governance. Three Faces of Power. 2003/4.

73. Petros Gemtos, Universität Athen: Methodologische Probleme der Kooperation von Rechts- und Wirtschaftswissenschaft. 2003/3. 